$$
\begin{gathered}
\text { カラーレスセラモメタルクラウンヘの } \\
\text { 試作光重合型モノマーの応用 } \\
\text {-マージン修正用ポーセレンの築盛一 }
\end{gathered}
$$

\author{
浅尾武 \\ 九州歯科大学大学院歯学研究科歯科補綴学第 2 専攻（指導：内田康也教授） \\ 九州歯科大学歯科理工学講座（指導：小園凱夫教授） \\ 平成 3 年 12 月 25 日受理
}

\title{
Application of Experimental Light-curing Monomer \\ to Collarless Ceramo-metal Crown \\ - Forming of Shoulder Porcelain -
}

Takeshi Asao

\author{
Second Department of Prosthetic Dentistry (Director: Prof. Yasunari Uchida) \\ Department of Materials Science (Director: Prof. Yoshio Kozono) \\ Kyushu Dental College, Kitakyushu, Japan
}

Collarless ceramo-metal crowns have been widely used because of their superior esthetics at the shoulder as well as the protection of the gingival margin from direct exposure to metal. There are, however, some difficulties in fabricating the crown with satisfactory marginal fit and/or correcting the contour of the loosely fitting porcelain shoulder. In order to overcome such problems in this study, the light-curing process was attempted for forming the porcelain with the experimental monomers. The monomers were composed of $1,3-$ butanediol dimethacrylate monomer (BDMA) as a base monomer, glycidil methacrylate monomer (GMA) as a diluent, dl-camphor quinone as a photosensitizer, and N, N-dimethyl-ptoluidine as a reducing agent. Four monomers with different BDMA to GMA ratios were prepared : 1:0 (referred to as $\left.\mathrm{M}_{1-0}\right), 1: 1\left(\mathrm{M}_{1-1}\right), 1: 1.5\left(\mathrm{M}_{1-1.5}\right)$, and $1: 2\left(\mathrm{M}_{1-2}\right)$. Their performances were discussed by comparing with the porcelain formed with distilled water followed by firing at $900^{\circ} \mathrm{C}$ as a control.

The porcelain formed by the light-curing process showed 10 to $15 \%$ larger volumetric shrinkage in firing than the control because the porcelain powders could be less incorporated in the mixture with the viscous monomers. The shrinkage not only compensated for the lowered density of the porcelain but also markedly reduced the size of porosities except for the monomer $\mathrm{M}_{1-0}$ that produced significantly larger size and number of porosities in the fired porcelain. It was reflected in the compressive strength not smaller than that of the control.

When the porcelains formed with the monomers were fired at a temperature lower than 
$850^{\circ} \mathrm{C}$, the shade turned blackish due to the incomplete combustion of the polymers. However, distinguishable color differences could no more be found after firing at $900^{\circ} \mathrm{C}$ among the control and the porcelains formed with $\mathrm{M}_{1-0}, \mathrm{M}_{1-1}$ and $\mathrm{M}_{1-1 . \overline{5}}$.

The monomers were applied to form the shoulder porcelain at the margin of the collarless ceramo-metal crown on the plaster die to correct its margin contour. When distilled water was routinely used, a considerable amount of porcelain powders remained on the die shoulder in lifting the crown. With the use of $\mathrm{M}_{1-0}$ and $\mathrm{M}_{1-1}$, however, almost all the powders could be withdrawn as a bulk from the die together with the crown, although no improvements were found on the separation from the die with $\mathrm{M}_{1-1.5}$ and $\mathrm{M}_{1-2 .}$. As a result, the margins showed excellent fit to the die shoulder after firing when $M_{1-0}$ and $M_{1-1}$ were used for formation, while larger marginal gaps were observed in the cases of the control and the other two monomers.

From the foregoing findings, it was suggested that the light-curing forming of the shoulder porcelain with the experimental monomer $\mathrm{M}_{1-1}$ would be an extremely useful technique for improving the workability and marginal fit without adversely affecting the physical and mechanical properties.

Key words : Collarless ceramo-metal crown/BDMA monomer/Light-curing/Shoulder porcelain forming

\section{緒言}

審美的な修復物として陶材焼付鋳造冠が応用されるよ うになって 30 年が経過した。 しかし，その予後に関し て種々な問題が提起されており，十分に解決されていな い部分も残されている．そのひとつに歯頸部辺縁歯肉に みられる変色がある．また，唇側マージン部が金属であ ることから，金属色の透過や金属の露出による審美性が 問題となってきた ${ }^{1-5\rangle}$. その対策として，メタルカラーを 薄くしたり，金メッキしたりする方法などが紹介された が，根本的な対策法にはならなかった。

そこで，マージン部の金属の露出を防ぐ方法として， 1956 年, Brecker ${ }^{5)}$ によってポーセレンマージンを持つ カラーレスセラモメタルクラウンが考案された。 このカ ラーレスセラモメタルクラウンは唇側マージン部の審美 性の問題を解決でき, マージン部の色調, 強度および従 来の陶材焼付鋳造冠の利点を合わせあつものである．ま た，マージン部にメタルが露出しないため，マージンを 歯肉同縁に設定することができるようになってきた。

カラーレスセラモメタルクラウンの作製方法には, 白 金箔”および耐火模型材による方法やダイレクトリフト 法8.97などがある。しかしながら，これらの方法では技 工操作上問題点が多く, 適合のよい修復物は得られな
い，白金箔による方法では箔の雬型への圧接不足や箔を 取り除いたときのポーセレンマージンの破折に起因する マージン部の適合性が問題となってきた。 また, 耐火模 型材による方法では模型材自体の強度不足や操作の繁雑 さなどの難点があり，ダイレクトリフト法では築盛した マージン部のポーセレン泥の一部が歯型に付着するた め, 霜型からの脱離が困難である. ワックス・ポーセレ ン・テクニックにおいても, ワックスの粘度ならびに表 面張力が大きくて多量のポーセレン粉末を混入させるこ とができず，コンデンスあ十分に行えないため，ポーセ レン内部に気泡が生じやすい.さらに,これらの方法で は，いずれもポーセレン焼成時の収縮が大きいために十 分な適合性が得られず，グレージング後にマージン部の 修正を必要とする. グレージング後のマージン部の間隙 量は $100 \mu \mathrm{m}$ といわれており，この間隙にポーセレン泥 を築盛することは技工操作上困難である.この問題を改 善するために近年, 光重合方式によるポーセレンマージ ンの築盛法が紹介された10,11). しかし，この方法もいま だ確立されておらず，マージン部修正用ポーセレンに応 用した場合, 白濁や黒変によるポーセレンへの色調に対 する影響など新たな問題が生じてきだ22.

そこで, 本研究では, 光重合法を応用したポーセレン 築盛用混和モノマー液を試作し, カラーレスセラモメ夕 
ルクラウンの作製操作を容易にするととむに適合性, ポーセレンの色調などの問題点を改善することを試み, 臨床応用の可能性を検討した。

\section{材料およひ方法}

予備実験において，応用可能と思われる数種類のモ， マーを選び, 粘度, 焼成時のススの発生の有無, ポーセ レンの変色などについて検討した結果，1，3-ブタンジ オールジメタクリレート（BDMA）があっとも好まし いものであることがわかった. したがって，この BDMA をべースモノマーとして，これに光増感剤 $\mathrm{dl}-$

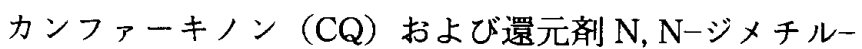
p-トルイジン（DMPT）をそれぞれ $1 \mathrm{wt} \%$ 割合で配 合し，光重合型モノマーを作製した。 また，希釈剤には グリシジルメタクリレート（GMA）を選び, Table 1 に示すように容積比で $1 ： 1 ， 1 ： 1.5$ および $1 ： 2$ の 割合に希釈した。

ポーセレンにはマージン修正用ポーセレン (CPM パ ウダー，松風）を使用した. 蒸留水を用いて十分コンデ ンスを行いながら築盛し，乾燥・焼成したものをコント ロールとした，光重合法による築盛にあたっては，ポー セレン粉末を試作モノマーと混和し，蒸留水の場合と同 様にコンデンスを行った後，可視光線を照射して重合さ

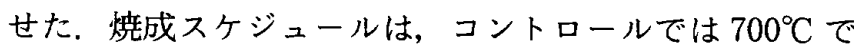
5 分間乾燥後, $900^{\circ} \mathrm{C}$ まで加熱して焼成した. 光重合型 モノマーで築盛したものでは， $700^{\circ} \mathrm{C}$ で乾燥するとポリ マーが急激な燃焼を起こしてポーセレン全体に著しい黒 変が生じたので, $650^{\circ} \mathrm{C} て ゙ 5$ 分間乾燥後, $900^{\circ} \mathrm{C}$ まで加 熱して焼成した。 また，減圧焼成の場合， $880^{\circ} \mathrm{C}$ まで減 圧下で昇温し，そこで大気圧に戻して $900^{\circ} \mathrm{C}$ まで加熱し

Table 1 Experimental light-curing momoners used for porcelain forming

\begin{tabular}{lccc}
\hline \hline Code & Base & Diluent & Base $/$ Diluent \\
\hline$M_{1-0}$ & BDMA & - & - \\
$M_{1-1}$ & BDMA & GMA & $1 / 1$ \\
$M_{1-1.5}$ & BDMA & GMA & $1 / 1.5$ \\
$M_{1-2}$ & BDMA & GMA & $1 / 2$ \\
\hline
\end{tabular}

control Distilled water

BDMA : 1,3-butanediol dimethacrylate monomer

GMA : glycidil methacrylate monomer All the monomers includedl-camphor quinone as a photosensitizer and N,N-dimethyl-ptoluidine as a reducing agent.
た.

以下の実験にはそれぞれ 5 個の試験片を作製し，測定 ならびに観察を行った。

I . 焼成収縮，気泡および圧縮強さ

蒸留水拉よび各モノマーをそれぞれ $0.15 \mathrm{ml}$ ガラス練 板上にとり，予め科量した一定量のポーセレン粉末から 築盛可能な範囲内でできるかきり多くの粉末を混和液中 に混入させ，その粉末の残余量から各液への最大粉末混 入量を求めた.この結果をそれぞれの最適混和比亡し, 以後の試験片築盛にはすべてこの比になるように科量し て混和した。

直径 $6 \mathrm{~mm}$, 厚さ $3 \mathrm{~mm}$ モールドに築盛した各試験片に ついて，焼成後の空気中ならび蒸留水中での重量測定か ら, 体収縮率および密度を算出した。 その後, 試験片を 包埋して断面を研磨し, ポーセレン内部の気泡を顕微鏡 観察するとともに，画像解析処理装置（PIAS LA-4, PIAS）を用いて気泡の数および面積率を求めた．この とき直径 $10 \mu \mathrm{m}$ 以上の大きさの気泡を検出することを 目標として観察倍率を設定したが，測定後計算した結 果, 検出対象となった最小の気泡は $48 \mu \mathrm{m}^{2}$ （值径 7.8 $\mu \mathrm{m})$ の大きさであった.

また，蒸留水および $\mathrm{M}_{1-0}$ モノマーを用いて泥和・築盛 し，700-900 C で焼成したポーセレンの断面について， 顕微鏡観察により各温度での内部構造ならびに気泡の状 態を調べた。

圧縮試験は万能引張試験機（TENSILON UTM-III500 ,オリエンテック）を用い, クロスヘッドスピード $2 \mathrm{~mm} / \mathrm{min}$ で行った。試験片は直径 $3 \mathrm{~mm}$, 高さ $5 \mathrm{~mm}$ の モールドに築盛し，焼成後試験片の上下面を平行になる ように研磨した。

\section{II，表面性状}

直径 $3 \mathrm{~mm}$, 厚さ $2 \mathrm{~mm}$ モールドに築盛して焼成した試 験片を用いて, 光沢度および表面あらさを測定した. 光 沢度の测定には测色色差コンピュータ（ND-101-DC 型, 日本電色）を使用し, 各試験片とも任意の 3 ヶ所に ついて测定した結果から平均値を求めた，表面あらさの 剆定には万能表面性状測定機 (SE-3 C 型, 小坂研究 所）を用い，各試験片とも 3 力所で測定を行って 10 点 平均あらさを算出した。

また，走查電子顕微鏡（JSM T-300, 日本電子）に より表面状態を観察した。

\section{III. 色調}

直径 $3 \mathrm{~mm}$, 厚さ $2 \mathrm{~mm}$ の試験片について, 測色色差コン ピュータを用いて色度, 明度および色差を測定した。 ま 
た，モノマーで筑盛した場合の厚さの影響を調べるた め， $\mathrm{M}_{1-0}$ を用いて $5 \mathrm{~mm}$ までの厚さの試験片を作製し，同 様の測定を行った，さらに，蒸留水および $\mathrm{M}_{1-0}$ の場合 に対して, $700-900^{\circ} \mathrm{C}$ での焼成温度による色調の変化 についてあ調べた．各試験片とも任意の 5 点で測定し, その平均值を求めた.

IV. 歯型との分離性

適合性試験用金型としてマージン部が $90^{\circ}$ のショル ダーでテーパー 50 のクラウンの支台金型を用いた，通 法に従い金型の印象採得を行って，超硬せっこうを注入 し，模型上でカラーレスセラモメタルクラウンを作製し た. グレージングまで行った後, 作業模型上でのクラウ ンのマージン部とフィニッシングラインとの間隙量を読 み取り顕微鏡で測定した，その後，蒸留水を用いた通法 と光重合法によって，作業模型上でマージン部修正用 ポーセレン（CPM パウダー，松風）を築盛した，築盛 にあたって分離剤は, 蒸留水を用いる場合はイソス ティッフ（レンフェルト）を, 光重合型モノマーの場合 はジーセラセパレーター（GC）を使用した。

築盛後クラウンを作業模型から撤去し, 作業模型ショ ルダー部に付着して残留したポーセレン粉末を実体顕微 鏡で観察した．焼成後，クラウンを再び作業模型に戻 し,クラウンマージンと作業模型ショルダーとの間隙量 を読み取り顕微鏡で測定し，築盛前後の比較を行った。 その後,クラウンを作業模型にりん酸亚鉛セメント（エ リートセメント，GC）を用いてセメント合着し，包埋 して歯軸に沿って切断し，研磨した後金属顕微鏡でマー ジン部の辺縁形態ならびに適合状態を観察した。これら のクラウンの作製過程はすべて実体顕微鏡下で行った.

\section{結果}

I，焼成収縮，気泡および圧縮強さ

一定量 $(0.15 \mathrm{ml})$ の蒸留水㧍よび試作光重合型モ， マーに対して，築盛可能な範囲内で混入できるポーセレ ンの最大粉末量を Fig. 1 に示す. $\mathrm{M}_{1-0}$ に混入できる最 大粉末量は, 蒸留水の場合の $1 / 2$ 程度にすぎなかっ た，BDMA への希釈剂の添加量が多くなるにつれて粉 末混入量は增加し， $\mathrm{M}_{1-1.5}$ で蒸留水の場合の約 $75 \%$ に達 したが，それ以上希釈剤が増してあ粉末混入量の変化は みられなかった。

Fig. 2 は焼成によるポーセレンの体積収縮率を示し ている，大気焼成した場合，蒸留水を用いたコントロー ルで約 30\% の収縮がみられた，光重合型モノマーを用 いると収縮はかなり大きくなり $(\mathrm{p}<0.01), \mathrm{M}_{1-0}$ で

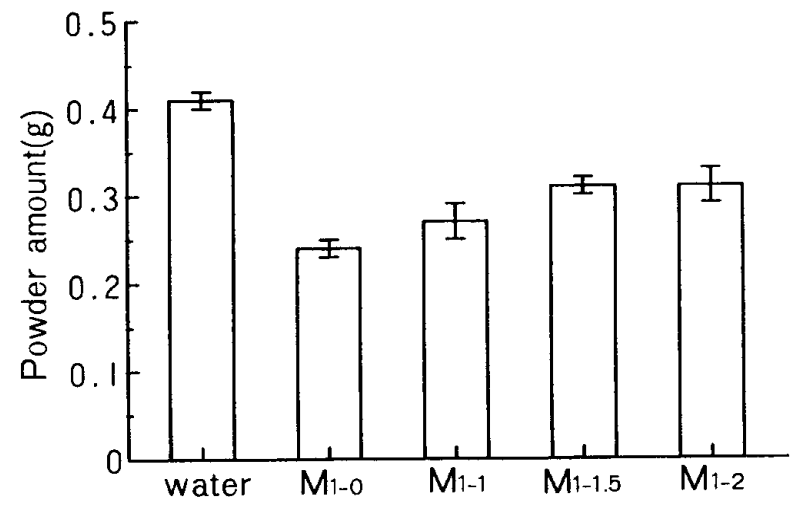

Fig. 1 Maximum amount of porcelain powder mixable with $0.15 \mathrm{ml}$ of liquid on forming.

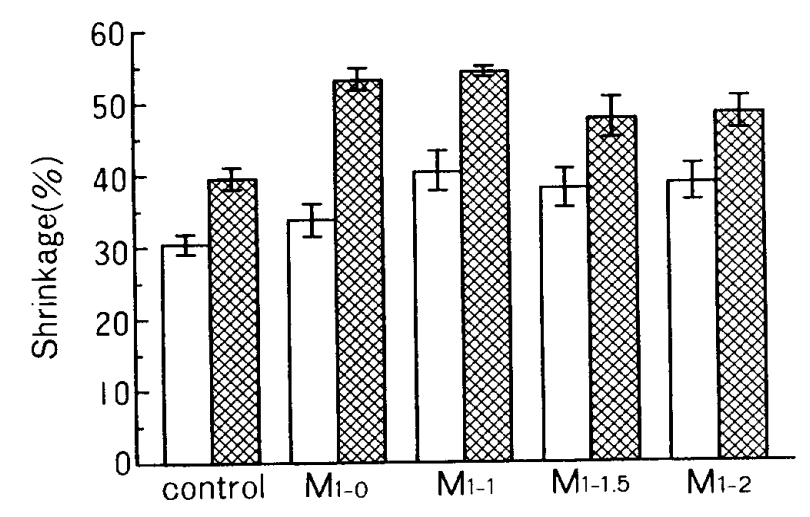

Fig. 2 Effect of mixing liquid on volumetric shrinkage of porcelain.

$\square$ in air under vacuum

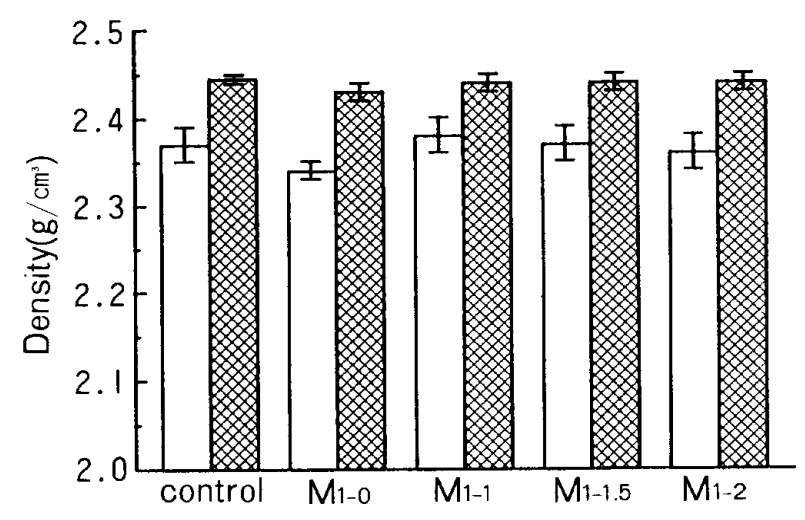

Fig. 3 Effect of mixing liquid on density of fired porcelain.

$\square$ in air under vacuum

35\%となった，希釈剤を含むモノマーを用いると収縮 はさらに大きくなり，いずれす $40 \%$ 前後であった. 減 圧陞成すると，いずれの場合も収縮は著しく大きくなっ 
たが，とくに $\mathrm{M}_{1-0}$ 抒よび $\mathrm{M}_{1-1}$ では $50 \%$ を越える大きな 収縮が認められた。

Fig. 3 は焼成後のポーセレンの密度を示している. 減圧焼成することによって, 大気焼成の場合より密度は 大きくなった，いずれの焼成においても， $\mathrm{M}_{1-0}$ のみがコ

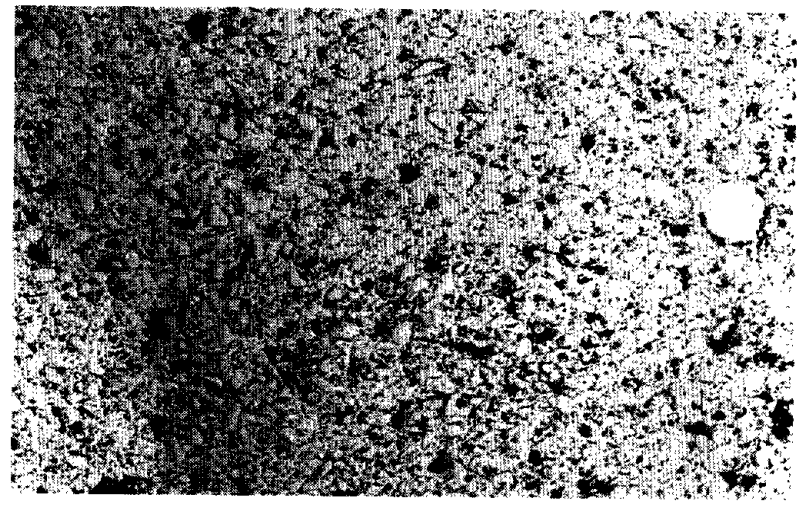

ントロールより小さな密度となり，他の希釈剂を含むモ ノマーではコントロールと同程度の密度であった。 ま た， $\mathrm{M}_{1-0}$ とコントロールとの密度の差は隇圧焼成するこ とによって幾分小さくなる傾向にあった。

本実験で用いたポーセレンの焼成温度は $900^{\circ} \mathrm{C}$ である
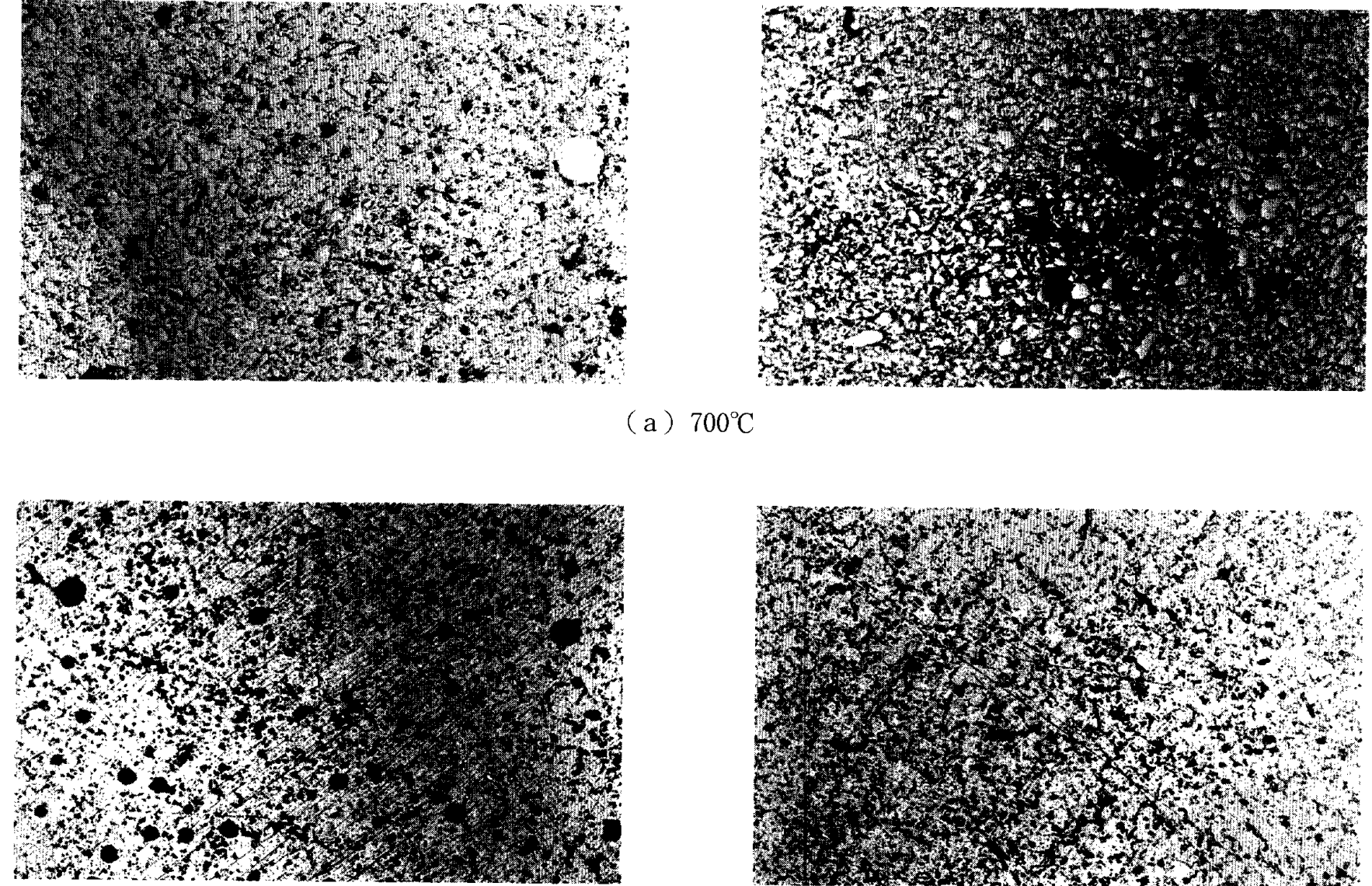

\section{(a) $700^{\circ} \mathrm{C}$}

(b) $750^{\circ} \mathrm{C}$
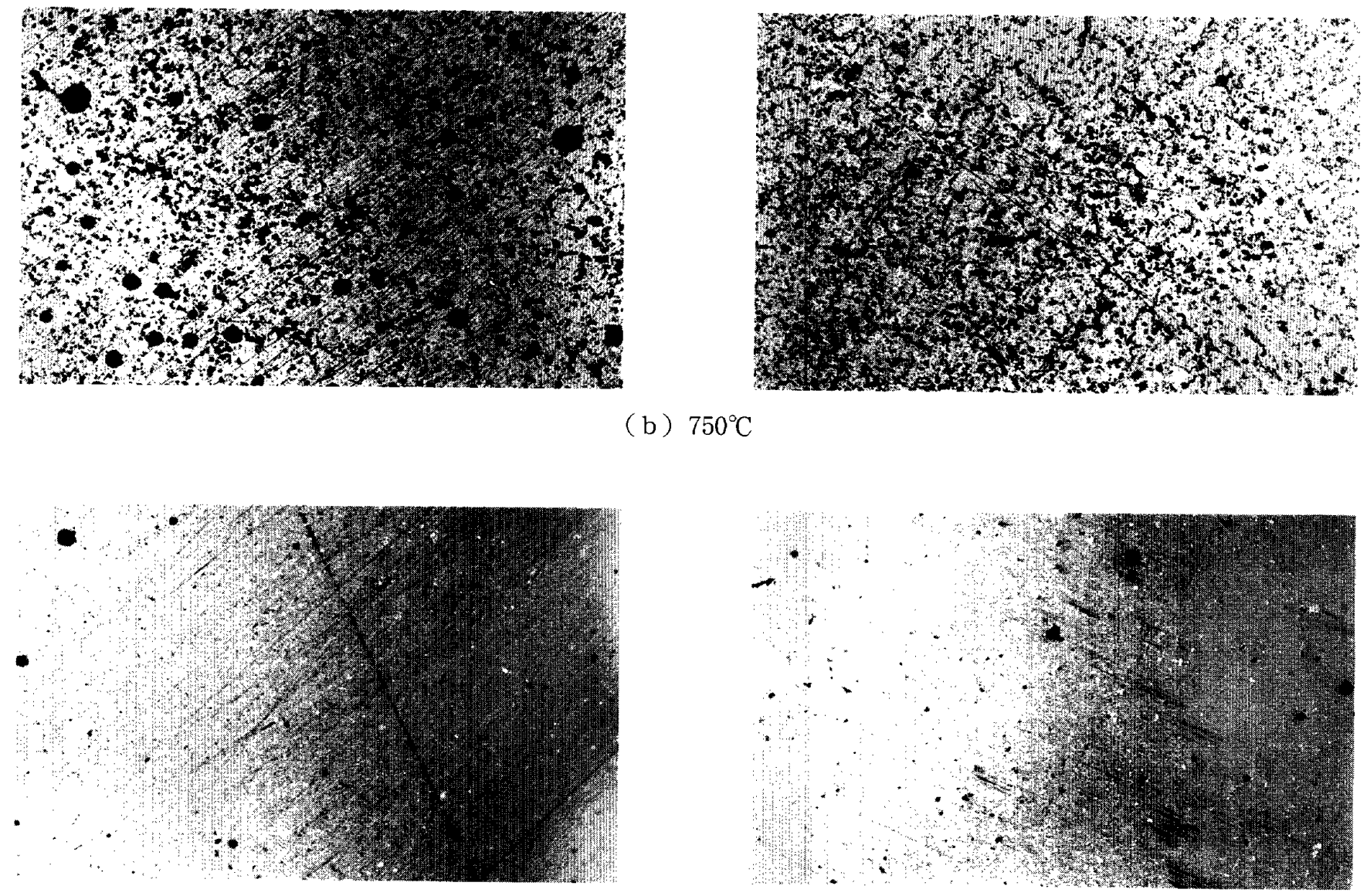

(c) $800^{\circ} \mathrm{C}$

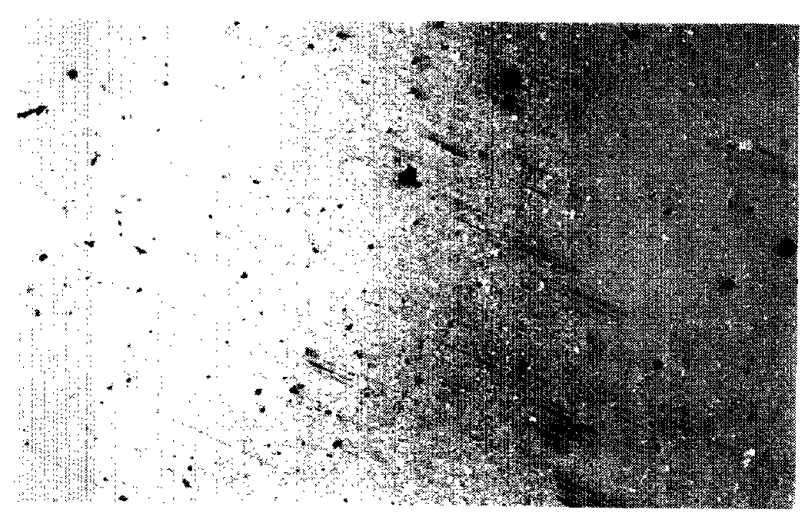

Fig. 4-1 Inside microstructure of porcelain fired under vacuum at different temperatures. left : formed with distilled water right : formed with $M_{1 \rightarrow 0}$ 

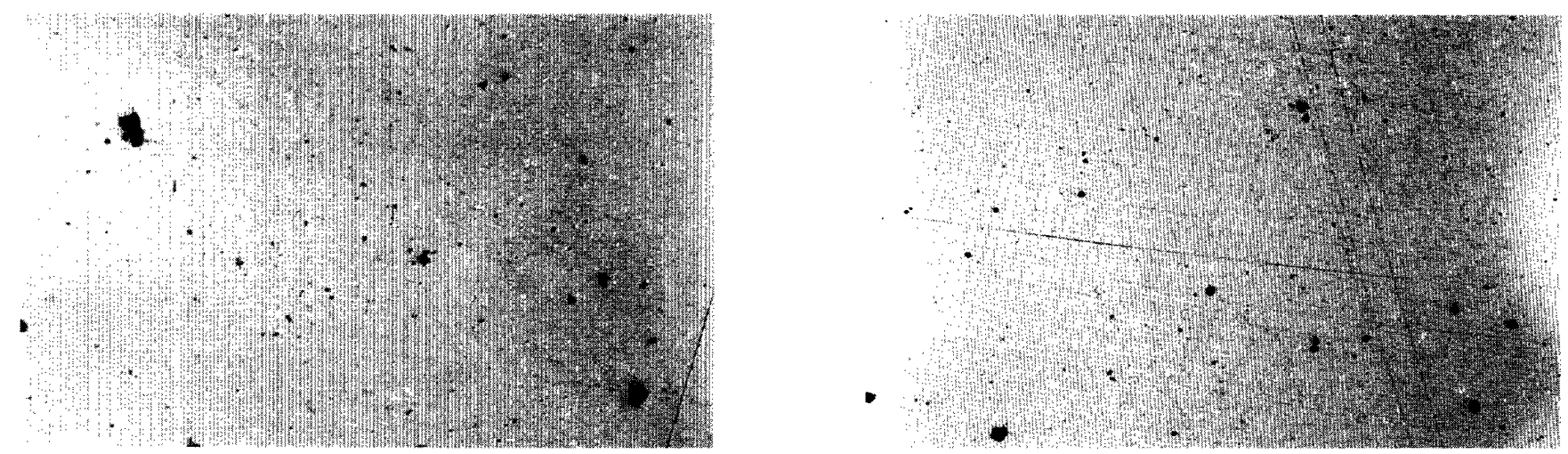

(d) $850^{\circ} \mathrm{C}$
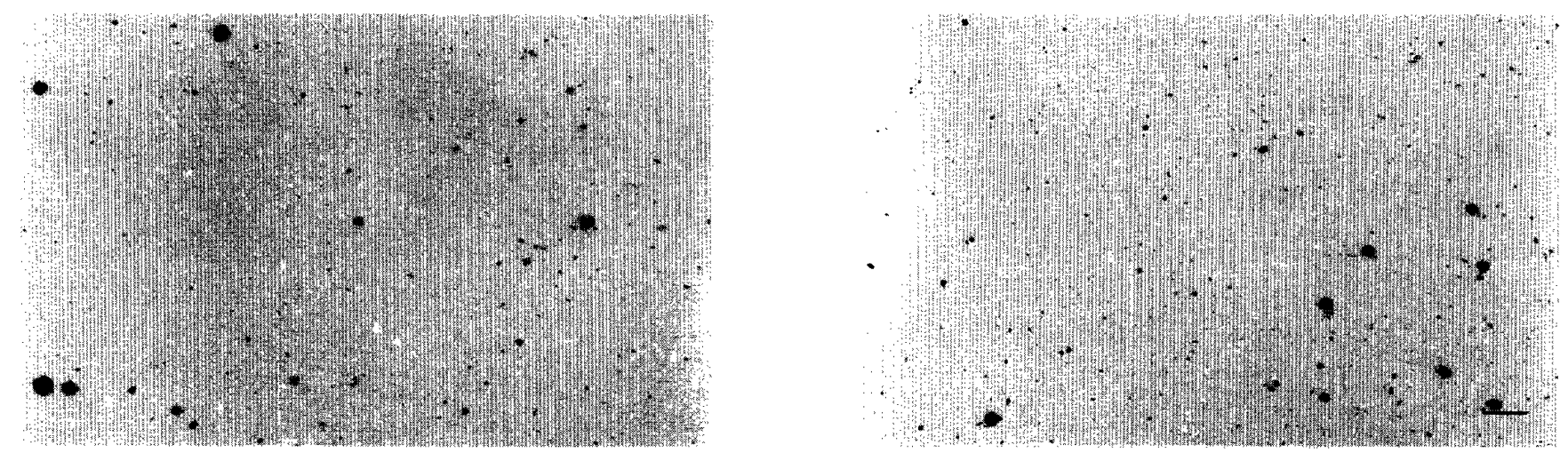

(e) $900^{\circ} \mathrm{C}$

Fig. 4-2 Inside microstructure of porcelain fired under vacuum at different temperatures. left : formed with distilled water right : formed with $M_{1-0}$

が, $700-900^{\circ} \mathrm{C}$ の温度で減圧焼成したときのポーセレ ン断面の顕微鏡写真を Fig. 4 に示す. 左は蒸留水を用

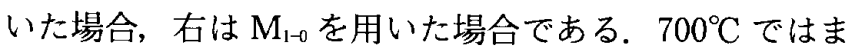
だポーセレン粉末が明瞭に観察される， $\mathrm{M}_{1-0}$ には大きな 空隙が数多く認められた. $750^{\circ} \mathrm{C} て ゙$ 焼成した試験片で は，粉末の表層が溶融して焼結し始めており，空隙は分 散して小さくなっていた. $800^{\circ} \mathrm{C}$ でほぼ全面で溶着した 様子がみられ，粒子の境界は識別できなくなった。この 段階で気泡の存在が明瞭になり， $\mathrm{M}_{1-0}$ には大きな気泡が 多く残留していた． $850^{\circ} \mathrm{C}$ おび $900^{\circ} \mathrm{C} て ゙$ 焼成した試験 片では, $800^{\circ} \mathrm{C}$ の場合と見かけ上変化は観察されなかっ た.

Fig. 5 は， $900^{\circ} \mathrm{C}$ で焼成したポーセレン断面に存在す る $48 \mu \mathrm{m}$ 以上の大きさの気泡を対象にして画像解析を 行い，定量的に比較した結果を示している. 数は $1 \mathrm{~mm}^{2}$ 当 たりの気泡の個数をあらわし，面積率は一定面積内で気 泡が占める割合（\%）をあらわしている。コントロール
においては，大気焼成によって $500 \mu \mathrm{m}^{2}$ 以上の大きな気 泡の数は $1 \mathrm{~m}^{2}$ 当たり約 12 個となり, 面積率で $4.3 \%$ を 占めていたが, 減圧焼成すると $500 \mu \mathrm{m}^{2}$ 以上の大きな気 泡は減少し, $48 \sim 50 \mu \mathrm{m}^{2}$ の小さな気泡が約 1.5 倍に増 加した. $\mathrm{M}_{1-0}$ の場合, 大気焼成を行うと $500 \mu \mathrm{m}^{2}$ 以上の 大きな気泡が著しく増加し，面積率で約 10\%を占めて いた．減圧焼成することによって $500 \mu \mathrm{m}^{2}$ 以上の大きな 気泡は半減し，小さな気泡が増加した。希釈したモ， マーを用いると, 大気焼成の場合で $500 \mu \mathrm{m}^{2}$ 以上の大き な気泡は著しく減少し， $100 \mu \mathrm{m}^{2}$ 以下の小さな気泡がコ ントロールの約 1.5 倍になった，減圧焼成することに よって大きな気泡だけでなく小さな気泡もコントロール より減少する傾向にあった．Fig. 6 は，対象とした 48 $\mu \mathrm{m}^{2}$ 以上のすべての気泡について加算した総数执よび総 面積率を示している．大気焼成した場合，コントロール に比べて $\mathrm{M}_{1-0}$ では気泡の数は変わらないまま面積率が 著しい増加を示したが， $M_{1-1}, M_{1-1.5}$ および $M_{1-2}$ では逆 
Size indices for porosity distribution in Fig. $5\left(\mu \mathrm{m}^{2}\right)$
A : 500
E : $300-350$
I : $100-150$
B : $450-500$
F : $250-300$
$\mathrm{J}: 50-100$
C : $400-450$
$G: 200-250$
$\mathrm{K}: 48-50$
D : $350-400$
$\mathrm{H}: 150-200$
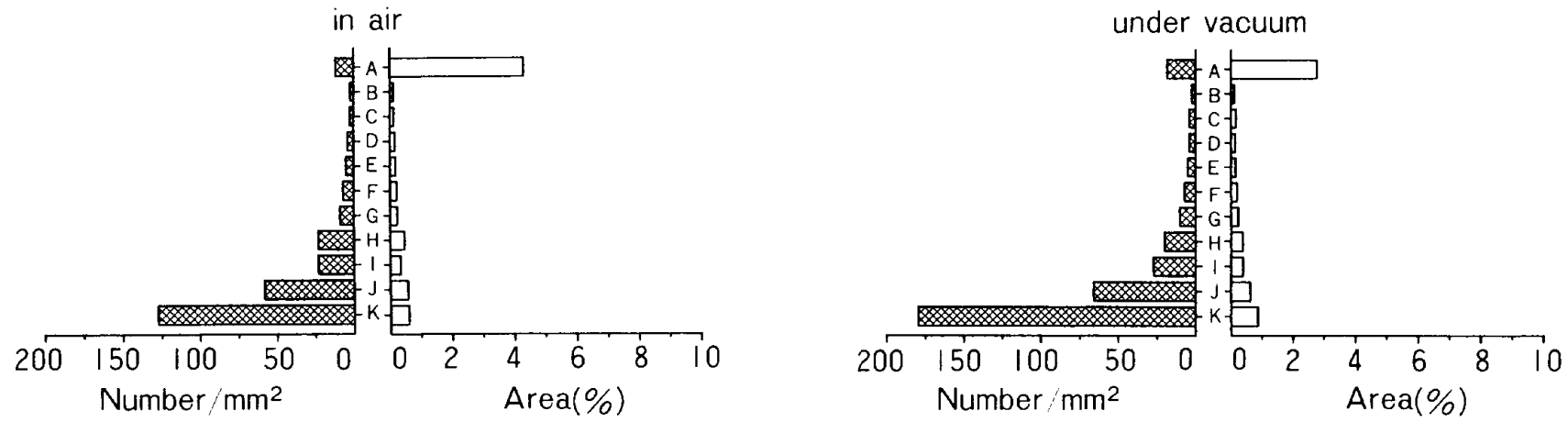

(a) control
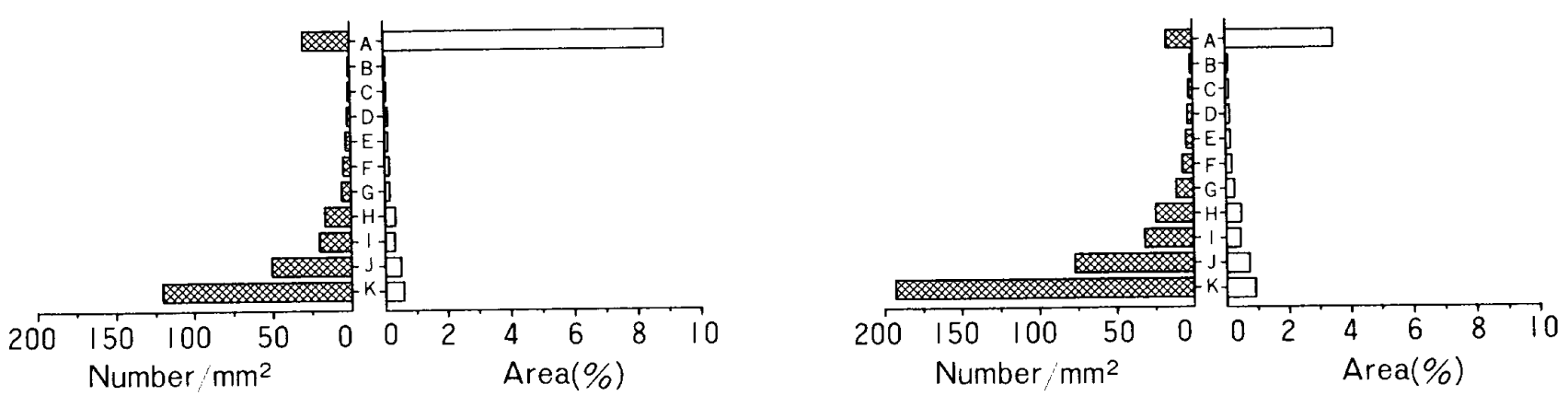

(b) $\mathrm{M}_{1-0}$
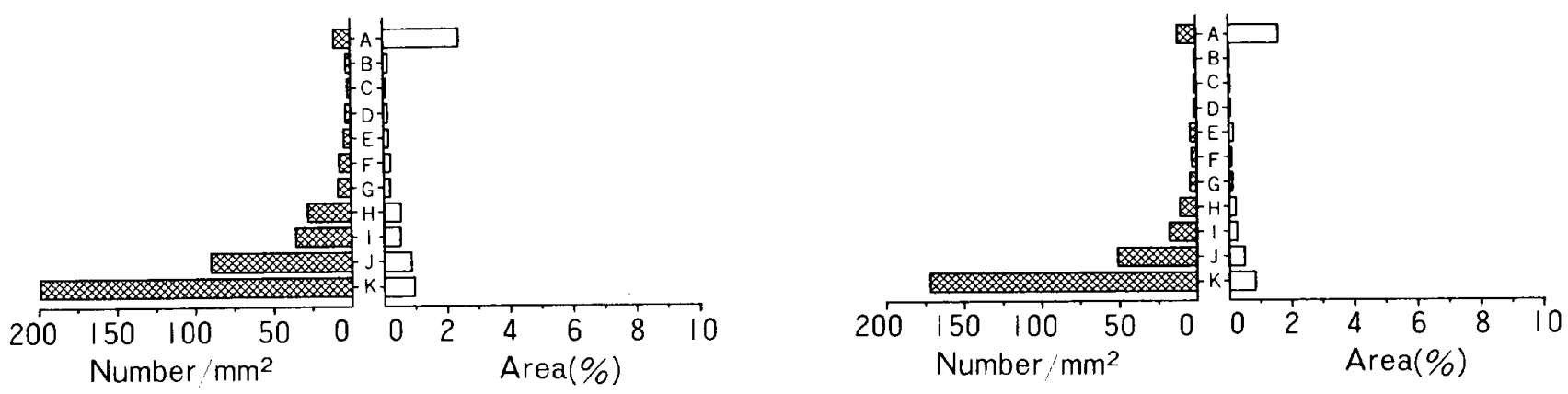

(c) $\mathrm{M}_{1-1}$

Fig. 5-1 Number and relative occupation area of porosity in fired porcelain. 

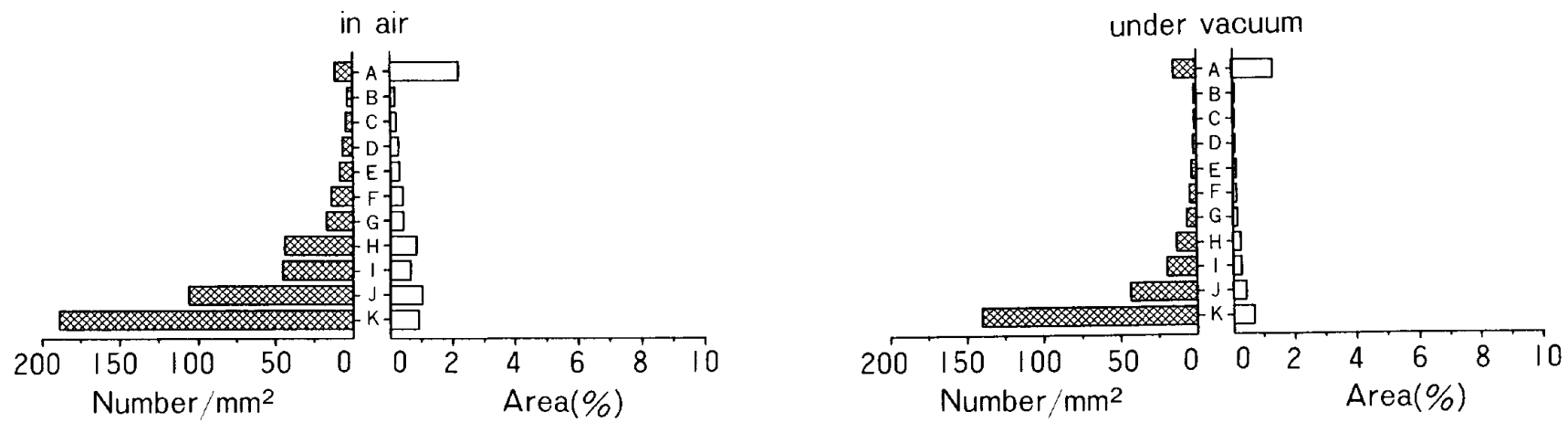

(d) $M_{1-1.5}$
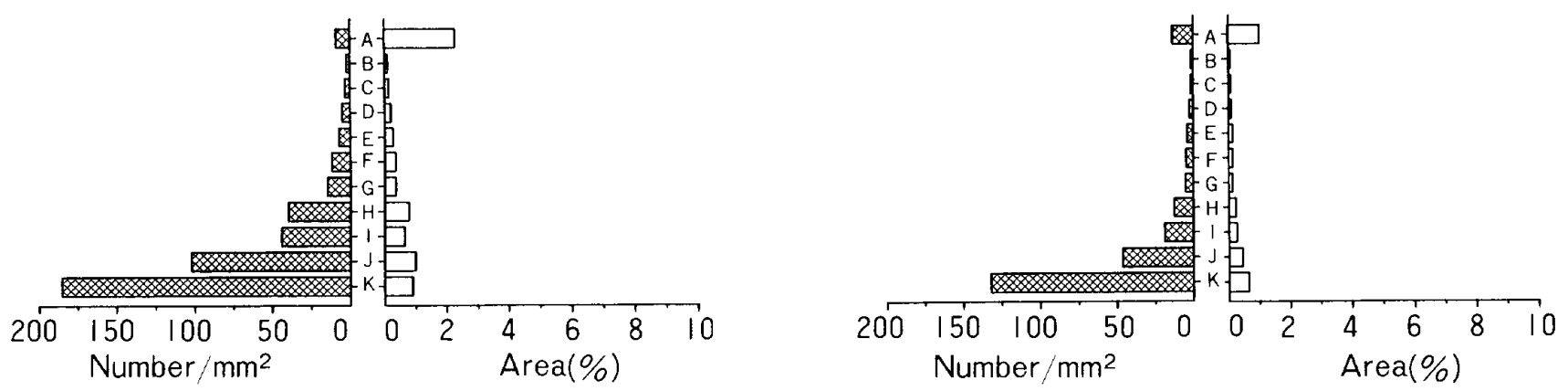

(e) $\mathrm{M}_{\mathrm{t}-2}$

Fig. 5-2 Number and relative occupation area of porosity in fired porcelain.
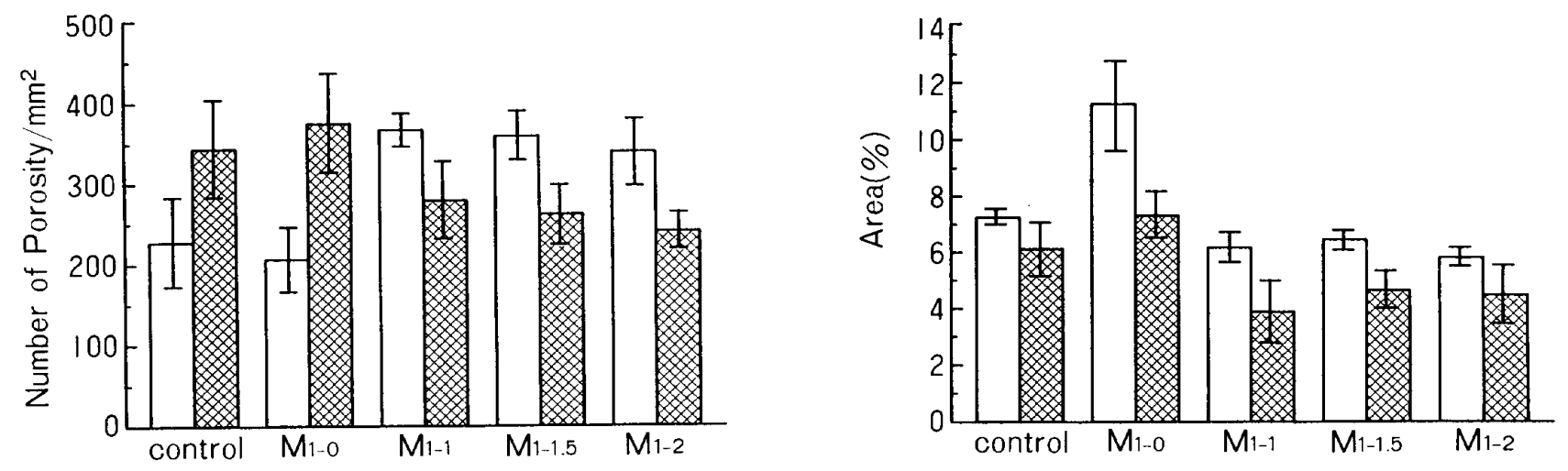

Fig. 6 Total number and relative occupation ares of porosity in fired porcelain. $\square$ in air under vacuum 


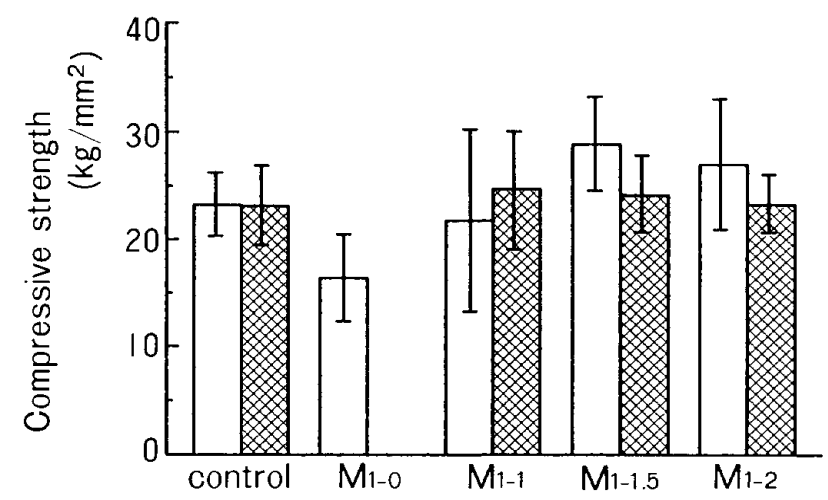

Fig. 7 Effect of mixing liquid on compressive strength of fired porcelain.

$\square$ in air under vacuum

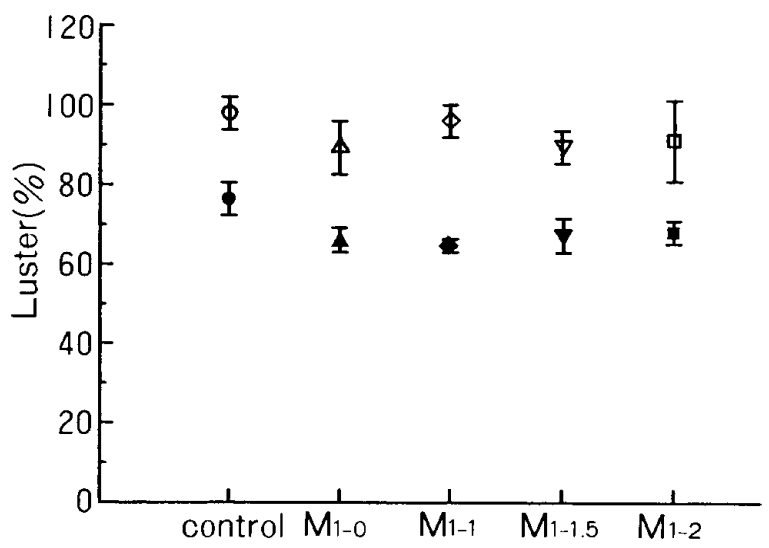

Fig. 9 Effect of mixing liquid on luster of fired porcelain.

open marks : in air

solid marks : under vacuum

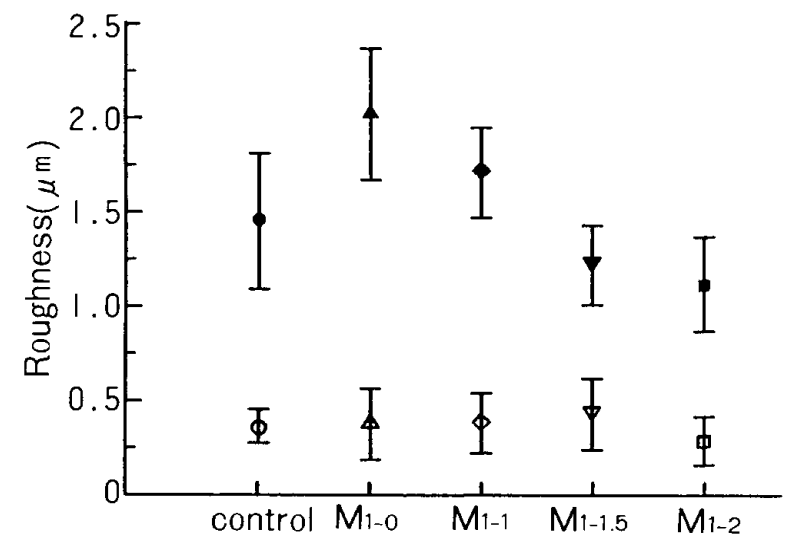

Fig. 10 Effect of mixing liquid on surface roughness of fired porcelain.

open marks : in air

solid marks : under vacuum
に数が著しく増加し，面積率は減少していた。滅圧焼成 すると，希釈剤を含むモノマーを用いた場合はいずれも 気泡の数, 面積率とすコントロールに比べて少なくなっ た.コントロールおよび $\mathrm{M}_{10}$ においては，減圧焼成に よって大気焼成した場合より面積率は減少し, 数が著し く増加する結果となった．この傾向はとくに $\mathrm{M}_{1-0}$ で顕 著にみられた。

焼成したポーセレンの圧縮強さを Fig. 7 に示す. $\mathrm{M}_{1-0}$ では，減圧焼成すると試験片に著しい变形が生じ, 圧縮試験が不可能であったため，図には $\mathrm{M}_{1-0}$ の減圧焼 成後の圧縮強さは示されていない。他の場合では, 大気 焼成と減圧焼成との間に大きな差はみられなかった。 $\mathrm{M}_{1-0}$ の圧縮強さはコントロールより著しく低下した。 し かし，希釈したモノマーを用いると，圧縮強さがコント ロールより同程度かあるいはコントロールをやや上回る ようになる傾向を示した。

II. 表面性状

Fig. 8 に焼成したポーセレン表面の走查電顕（SEM） 像を示す．大気焼成した場合には，モノマーを用いた試 験片とコントロールとの間で表面状態に大きな差はみら れず，いずれも減圧焼成に比べて平滑な表面であった。 隇圧焼成すると表面に凹凸が生じ，その凹凸はモノマー を用いた場合の方が大きくなる傾向にあった。しかし， 希釉剤の量の多少による变化は観察されなかった，表面 の光沢度は，Fig. 9 に示すようにいずれあ大気焼成し た場合の方が大きくなり，またモノマーを用いるとコン トロールより光沢度が低下する傾向がみられた，表面あ らさ值は大気焼成した場合著しく小さく，モノマーを用 いても変化は認められなかった（Fig. 10)。減圧焼成す ると、コントロールであらさ值は約 5 倍に増大した。 $\mathrm{M}_{1-0}$ ではさらに大きくなったが，希釈剤を加えることに よって小さくなり，また希釈剤の量が増すにつれて次第 に小さくなった。 しかし，全般的にあらさ值は小さく， 最大で $\mathrm{M}_{1-0}$ の $2 \mu \mathrm{m}$ であった.

III. 色調

焼成したポーセレン試験片について，CIE 表示による $\mathrm{x}, \mathrm{y}$ 值をプロットした色度図を Fig. 11 に示す. 大気 焼成および減圧焼成のいずれにおいても，コントロール 試験片之光重合型モノマーを用いた試験片との間で色度 に大きな違いはみられなかった。 また，モノマー希釈剂 の影響も認められなかった。

Fig. 12 は， $\mathrm{M}_{1-0}$ モノマーで築盛した場合のポーセレ ン試験片の厚さによる色度の変化を示している. 厚さ 4 mmまでは色度に大きな变化はみられなかったが，厚さが 

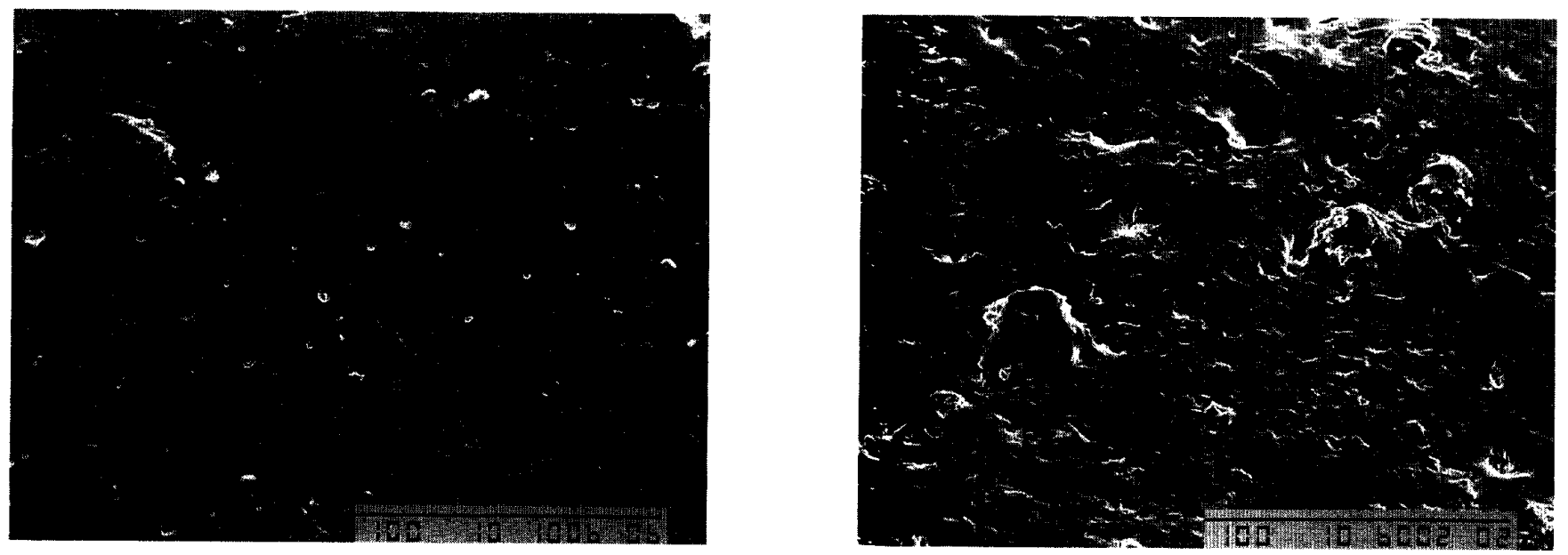

(a) control
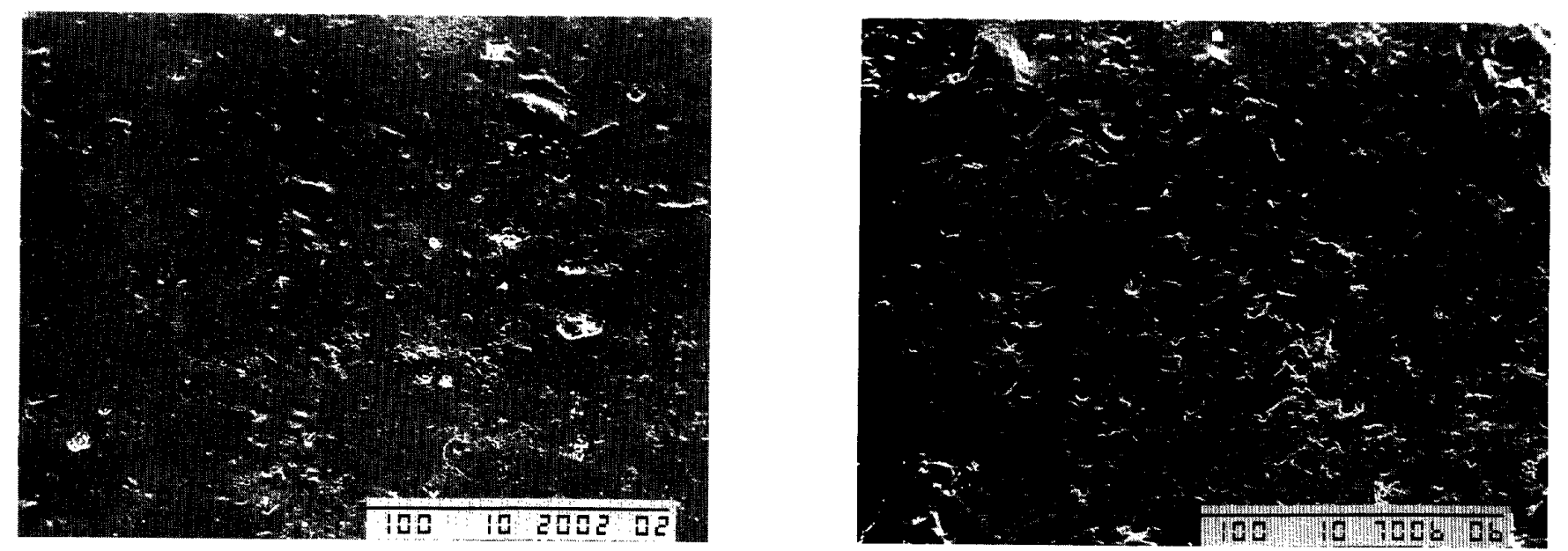

(b) $\mathrm{M}_{1-0}$
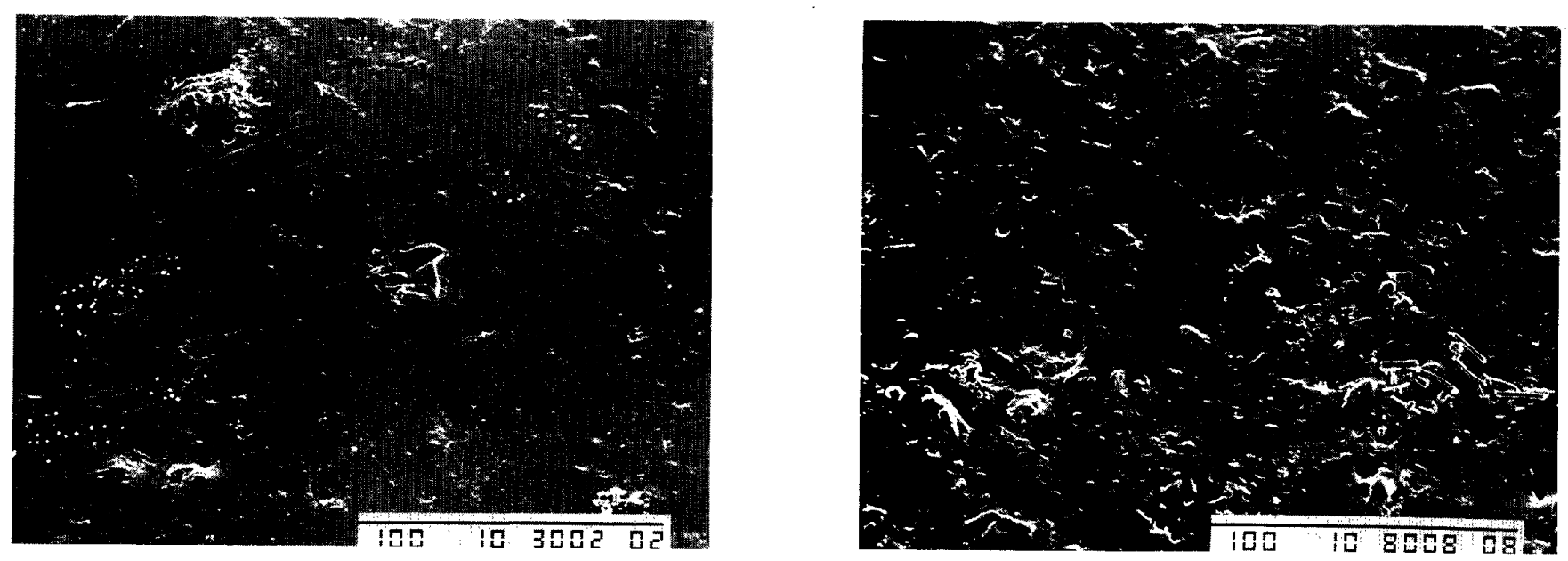

(c) $\mathrm{M}_{\mathrm{i}-1}$

Fig. 8 Surface aspects of porcelain fired in air (left) and under vacuum (right). 


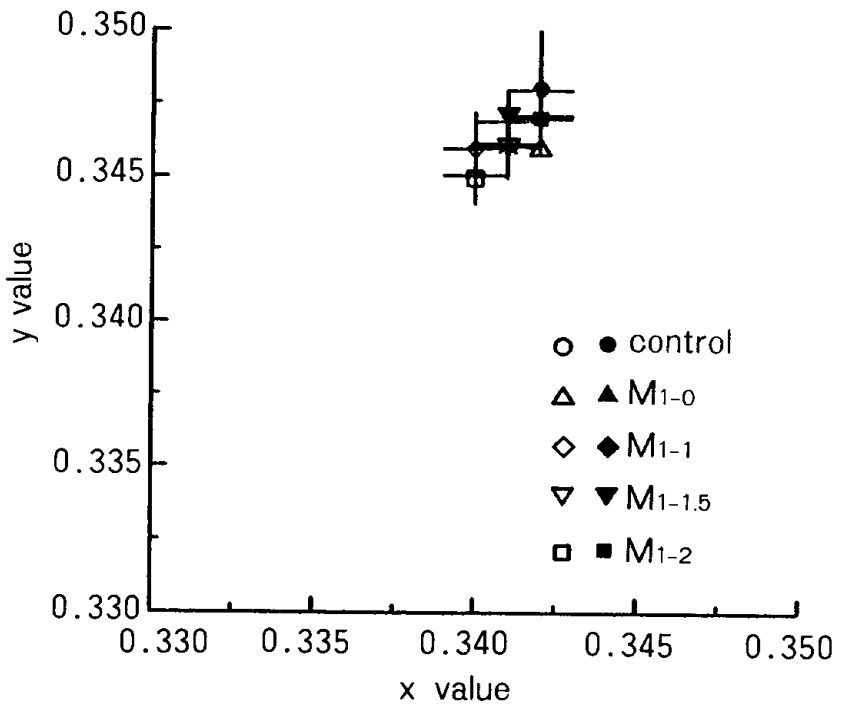

Fig. 11 Chromaticity coordinates of fired porcelain for each mixing liquid. open marks : in air solid marks : under vacuum

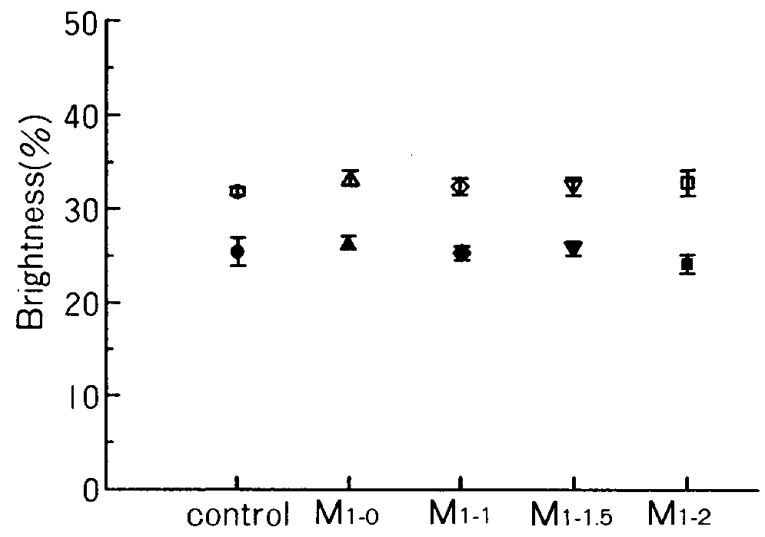

Fig. 13 Brightness of fired porcelain for each mixing liquid.

open marks : in air

solid marks : under vacuum

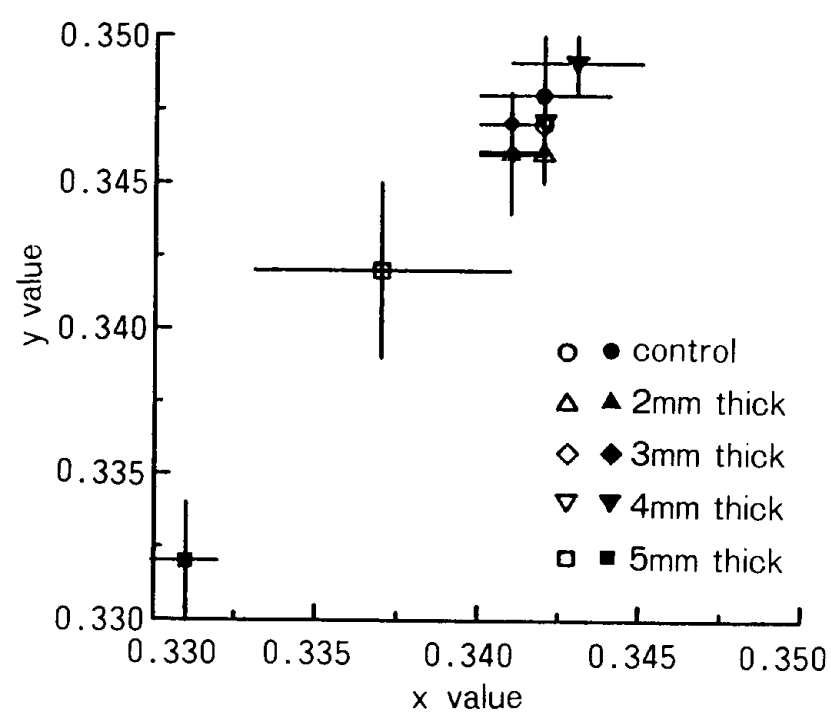

Fig. 12 Chromaticity coordinates of fired porcelain for each specimen thickness. open marks : in air solid marks : under vacuum

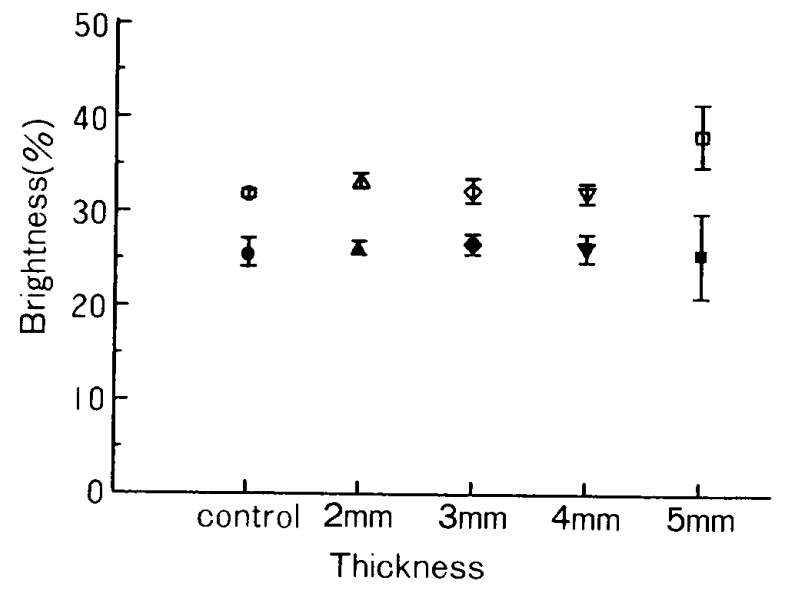

Fig. 14 Brightness of fired porcelain for each specimen thickness. open marks : in air solid marks : under vacuum

Table 2 Color difference of fired porcelain between the mixing liquids used for formation

\begin{tabular}{c|ccccc}
\hline \hline control & - & & & & \\
$M_{1-0}$ & 0.96 & - & & in air \\
$M_{1-1}$ & 0.36 & 0.34 & - & & \\
$M_{1-1.5}$ & 0.60 & 0.44 & 0.05 & - & \\
$M_{1-2}$ & 0.79 & 0.29 & 0.08 & 0.05 & - \\
\hline & control & $\mathrm{M}_{1-0}$ & $\mathrm{M}_{1-1}$ & $\mathrm{M}_{1-1.5}$ & $\mathrm{M}_{1-2}$ \\
\hline
\end{tabular}

\begin{tabular}{l|ccccc}
\hline \hline control & - & & & & \\
$\mathrm{M}_{1-0}$ & 0.54 & - & & under vacuum \\
$\mathrm{M}_{1-1}$ & 0.20 & 0.64 & - & & \\
$\mathrm{M}_{1-1.5}$ & 0.21 & 0.09 & 0.42 & - & \\
$\mathrm{M}_{1-2}$ & 1.45 & 2.67 & 0.80 & 2.20 & - \\
\hline & control & $\mathrm{M}_{1-0}$ & $\mathrm{M}_{1-1}$ & $\mathrm{M}_{1-1.5}$ & $\mathrm{M}_{1-2}$ \\
\hline
\end{tabular}


Table 3 Color difference of fired porcelain between specified thicknesses with use of $M_{1-0}$ for formation

\begin{tabular}{l|rccc}
\hline \hline $2 \mathrm{~mm}$ & \multicolumn{1}{|c}{} & & & \\
$3 \mathrm{~mm}$ & 0.64 & - & \multicolumn{2}{c}{ in air } \\
$4 \mathrm{~mm}$ & 0.99 & 0.23 & - & \\
$5 \mathrm{~mm}$ & 19.09 & 25.09 & 28.46 & - \\
\hline & $2 \mathrm{~mm}$ & $3 \mathrm{~mm}$ & $4 \mathrm{~mm}$ & $5 \mathrm{~mm}$ \\
\hline
\end{tabular}

\begin{tabular}{r|rrcc}
\hline $2 \mathrm{~mm}$ & \multicolumn{1}{|c}{-} & & & \\
$3 \mathrm{~mm}$ & 0.30 & - & under vacuum \\
$4 \mathrm{~mm}$ & 0.39 & 0.38 & - & \\
$5 \mathrm{~mm}$ & 11.75 & 14.77 & 16.14 & - \\
\hline & $2 \mathrm{~mm}$ & $3 \mathrm{~mm}$ & $4 \mathrm{~mm}$ & $5 \mathrm{~mm}$ \\
\hline
\end{tabular}

Table 4 Color difference of porcelain between firing temperatures

\begin{tabular}{r|rrrrr}
\hline \hline $700^{\circ} \mathrm{C}$ & \multicolumn{1}{|c}{-} & & & & \\
$750^{\circ} \mathrm{C}$ & 70.59 & - & \multicolumn{4}{c}{ with water } \\
$800^{\circ} \mathrm{C}$ & 264.16 & 180.42 & - & & \\
$850^{\circ} \mathrm{C}$ & 188.09 & 119.52 & 7.06 & - & \\
$900^{\circ} \mathrm{C}$ & 70.59 & 82.67 & 46.40 & 8.44 & - \\
\hline & $700^{\circ} \mathrm{C}$ & $750^{\circ} \mathrm{C}$ & $800^{\circ} \mathrm{C}$ & $850^{\circ} \mathrm{C}$ & $900^{\circ} \mathrm{C}$ \\
\hline
\end{tabular}

\begin{tabular}{c|cccccc}
\hline \hline $700^{\circ} \mathrm{C}$ & - & & & & \\
$750^{\circ} \mathrm{C}$ & 136.49 & - & & with $\mathrm{M}_{1-0}$ & \\
$800^{\circ} \mathrm{C}$ & 139.19 & 573.31 & - & & \\
$850^{\circ} \mathrm{C}$ & 192.75 & 638.66 & 4.39 & - & \\
$900^{\circ} \mathrm{C}$ & 116.68 & 476.66 & 4.36 & 14.28 & - \\
\hline & $700^{\circ} \mathrm{C}$ & $750^{\circ} \mathrm{C}$ & $800^{\circ} \mathrm{C}$ & $850^{\circ} \mathrm{C}$ & $900^{\circ} \mathrm{C}$ \\
\hline
\end{tabular}

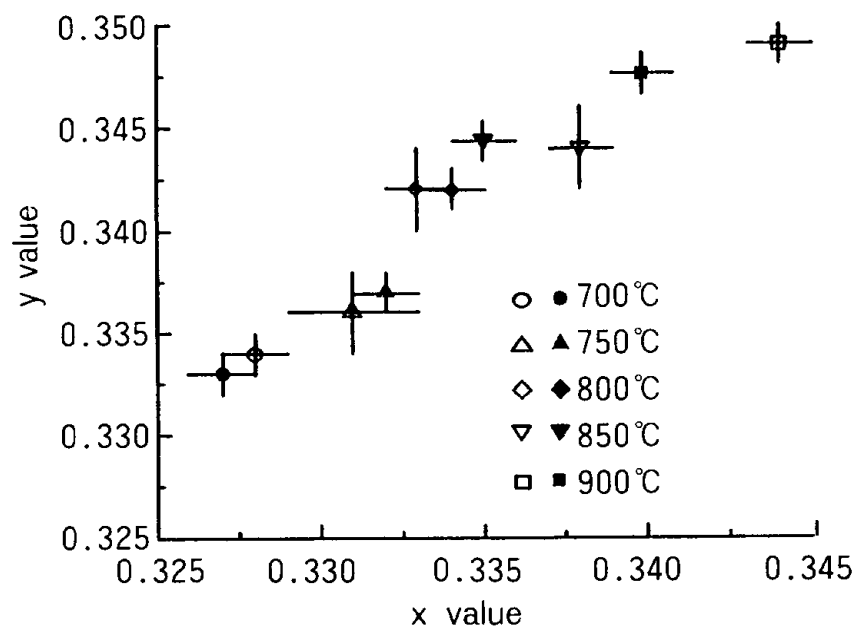

Fig. 15 Chromaticity coordinates of porcelain fired at particular temperatures. open marks : formed with distilled water solid marks : formed with $\mathrm{M}_{1-0}$

$5 \mathrm{~mm}$ になると $\mathrm{x}, \mathrm{y}$ 值ともに小さくなる傾向にあった. この傾向は，大気焼成より隇圧焼成した場合の方が大き かった。

ポーセレンの明度は, Fig. 13 に示すように光重合型 モノマーを用いて築盛しても, コントロールとほとんど 差はみられなかった，隇厈焼成することによって，大気 焼成に比べてポーセレンの明度は大きな低下を示した $(\mathrm{p}<0.01)$. Fig. 14 は明度におよぼすポーセレンの厚
Table 5 Color difference of fired porcelain between distilled water and $M_{1-0}$ used as the liquid for formation

\begin{tabular}{c|c}
\hline \hline $\begin{array}{l}\text { Firing } \\
\text { temperature }\end{array}$ & $\begin{array}{l}\text { Color } \\
\text { difference }\end{array}$ \\
\hline $700^{\circ} \mathrm{C}$ & 2.38 \\
$750^{\circ} \mathrm{C}$ & 250.86 \\
$800^{\circ} \mathrm{C}$ & 19.88 \\
$850^{\circ} \mathrm{C}$ & 2.17 \\
$900^{\circ} \mathrm{C}$ & 0.16 \\
\hline
\end{tabular}

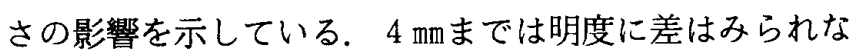

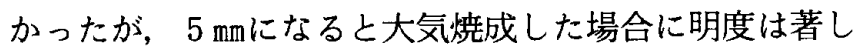
く大きくなった $(p<0.01)$. しかし, 減圧焼成では他 の厚さの試験片とほぼ同程度の明度であった。

Table 2 は各混和液を用いた場合のポーセレン間の色 差を示している. 大気焼成した場合，いずれの試験片の 間においてす色差値は 1 以下であった，減圧焼成すると $\mathrm{M}_{1-2}$ のみがコントロールならびに $\mathrm{M}_{1-0,}, \mathrm{M}_{1-1.5}$ との間で 幾分大きな色差を示したが, 他はいずれあ小さな值で あった，厚さが異なると Table 3 にみられるように， $4 \mathrm{~mm}$ まで色差は小さかったが, $5 \mathrm{~mm}$ で著しく大きな色 差が認められるようになった。 また，肉眼的にはいずれ の試験片にも黒変等は認められなかった。

Fig. 15 は蒸留水あるいは $\mathrm{M}_{1-0}$ を用いて築盛し, $700-$ 


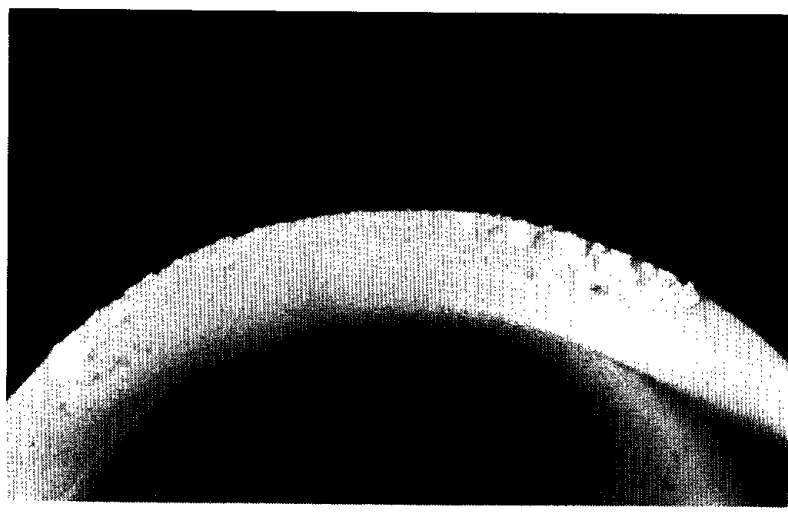

(a) distilled water

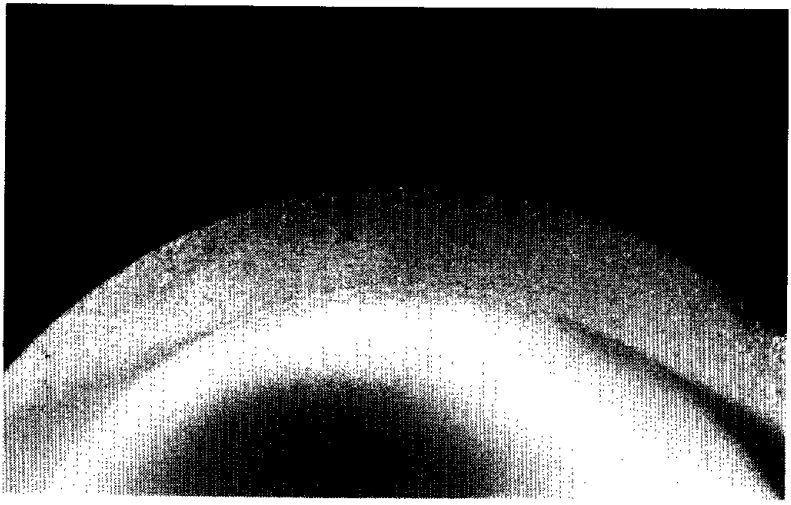

(c) $\mathrm{M}_{1-1}$

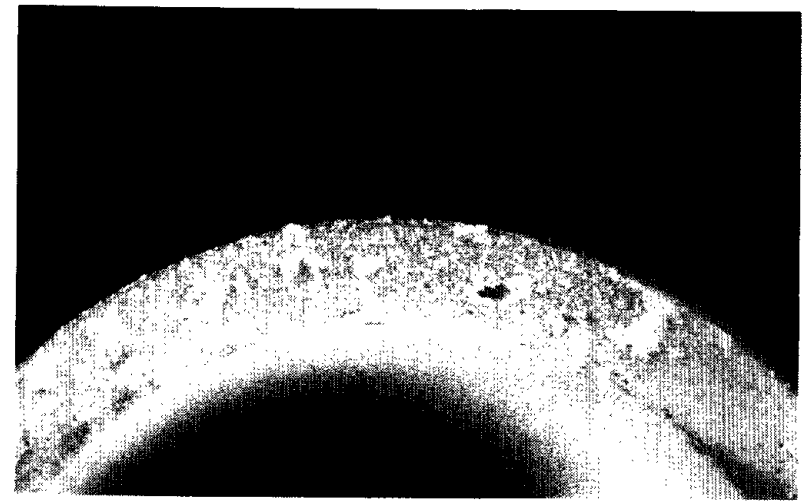

(e) $\mathrm{M}_{1-2}$

Fig. 16 Residual porcelain powders on the plaster die shoulder from the margin porcelain after direct lift following formation.

$900^{\circ} \mathrm{C}$ の異なった温度で焼成したポーセレンの色度を示 している．いずれの場合も焼成温度によって色度に変化 があらわれた。焼成温度 $800^{\circ} \mathrm{C}$ までは蒸留水之 $\mathrm{M}_{10}$ を 用いた場合とで色度にほとんど差はみられなかったが， 焼成温度 $800^{\circ} \mathrm{C}$ と $900^{\circ} \mathrm{C}$ の試験片では蒸留水を用いた場

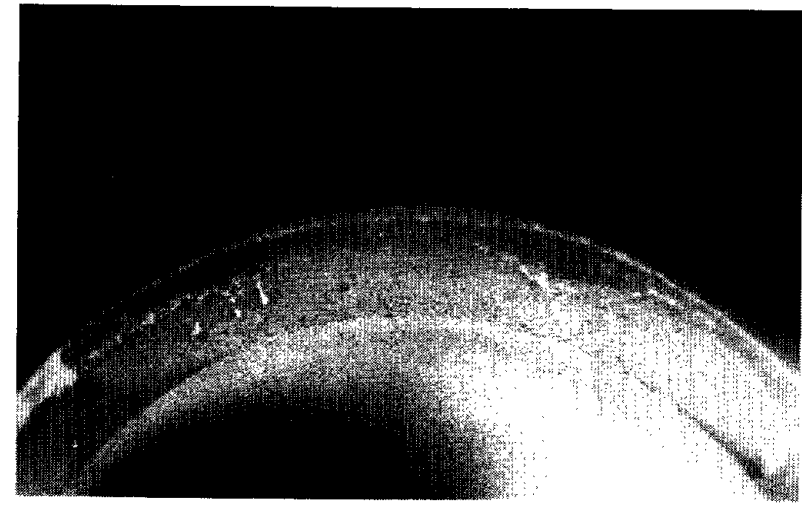

(b) $\mathrm{M}_{1-0}$

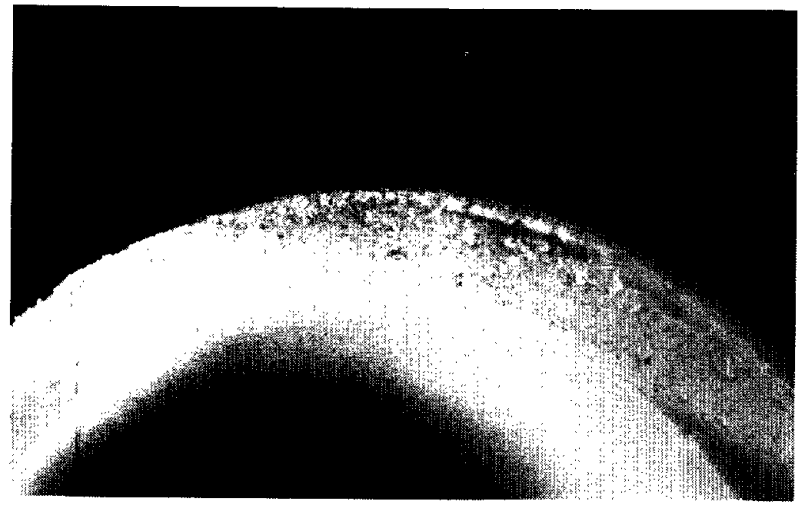

(d) $M_{1-1.5}$

合のほうが x 值が高くなる傾向にあった。

Table 4 には蒸留水あるいは $\mathrm{M}_{1-0}$ を用いて築盛し， 各温度で焼成したポーセレン間の色差を示している。 ま た, Table 5 は蒸留水を用いた場合之 $\mathrm{M}_{100}$ を用いた場 合の同じ焼成温度における色差を示している，焼成温度 によってポーセレンには著しい色差があらわれた。 とく

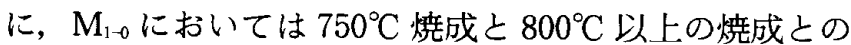
間に顕著な色差が生じた. $800^{\circ} \mathrm{C}$ を越えるといずれの場 合す色差が小さくなる傾向にあった，蒸留水を用いた場 合と $\mathrm{M}_{1-0}$ を用いた場合との間には $750^{\circ} \mathrm{C}$ 焼成で著しく 大きな色差がみられたが，焼成温度が高くなるにつれて 色差は激減していき， $900^{\circ} \mathrm{C}$ 焼成では 0.16 という小さな 色差となった，肉眼的には，蒸留水を用いて築盛した場 合， $700^{\circ} \mathrm{C}$ 焼成では白濁がみられたが，焼成温度が上昇 するにつれて白濁は消え透明感が増加した， $M_{1-0}$ を用い た場合には， $700^{\circ} \mathrm{C}$ 焼成では蒸留水の場合と同様に白濁 を示したが, $750-800^{\circ} \mathrm{C}$ の間でポーセレンに黒変が生 じ, $850^{\circ} \mathrm{C}$ でもわずかに黒変が認められた。 しかし， $900^{\circ} \mathrm{C}$ まで焼成温度が上昇すると黒变はほぼ消失し透明 感が得られるようになった。 
IV. 歯型との分離性

Fig. 16 はマージン部修正時に超硬せっこう歯型上に 残留したポーセレンを示している，ポーセレン築盛物を 歯型から撤去する際にその一部がはがれ，歯型ショル ダー部に残留したものが白い隆起物として観察される. 蒸留水を用いて練和した場合，かなり多量の残留がみら れた。 $\mathrm{M}_{1-0}$ および $\mathrm{M}_{1-1}$ の場合にはポーセレンの残留は わずかに認められたが，フィニッシングライン上には残 留していなかった。 しかし， $\mathrm{M}_{1-1.5}$ および $\mathrm{M}_{1-2}$ ではショ ルダー部フィニッシングライン上に蒸留水の場合と同様 にかなり多量のポーセレンが残留していた.

Fig. 17 はカラーレスセラモメタルクラウンの試適時 にフィニッシングライン上でみられたマージンと歯型 ショルダーとの間隙を示している. グレージング後の間 隙は $60 \mu \mathrm{m}$ 前後であった。ママージン部修正後には蒸留 水を用いた場合で約 $40 \mu \mathrm{m}$ となったが， $\mathrm{M}_{100}$ および $\mathrm{M}_{1-1}$ を用いて築盛すると間隙は $25 \mu \mathrm{m}$ にまで減少した。 さらに，希釈率が多くなると間隙は大きくなり， $\mathrm{M}_{1-2}$ で

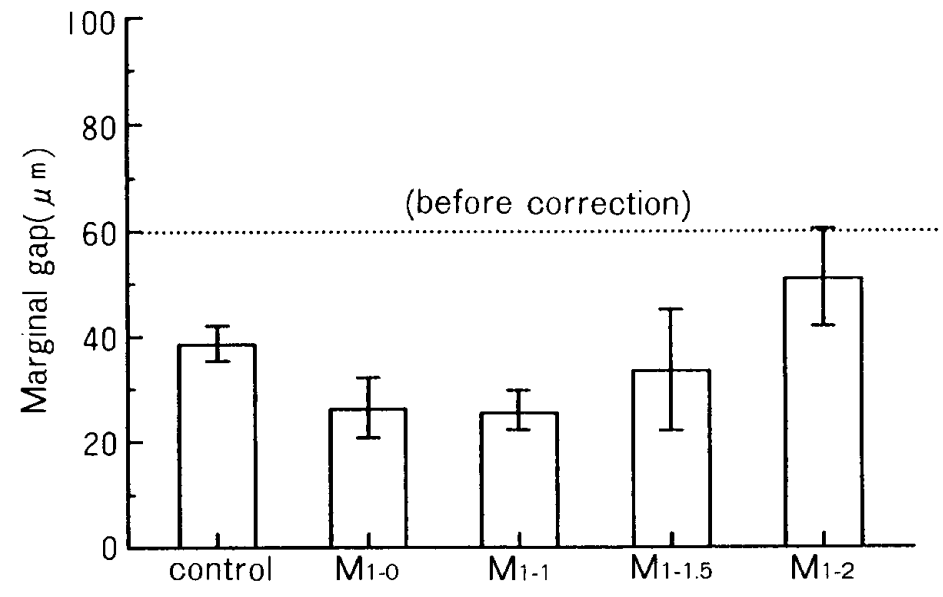

Fig. 17 Marginal gap of ceramo-metal crown with die shoulder after marginal correction.

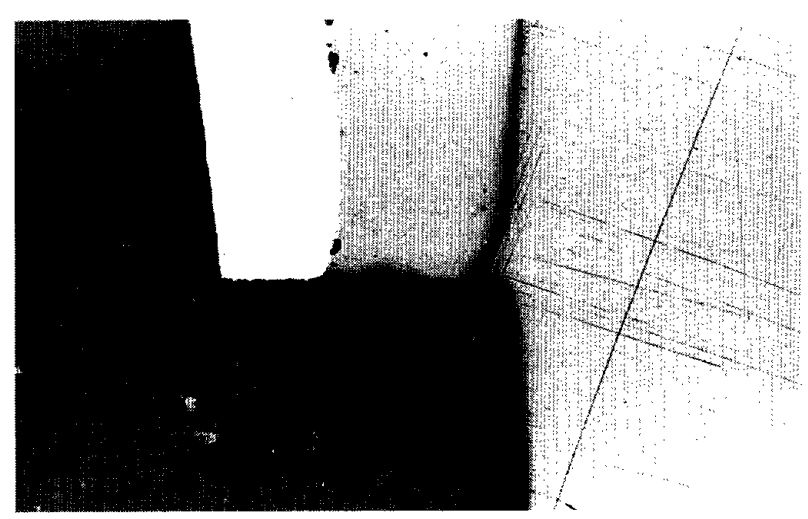

(a) control

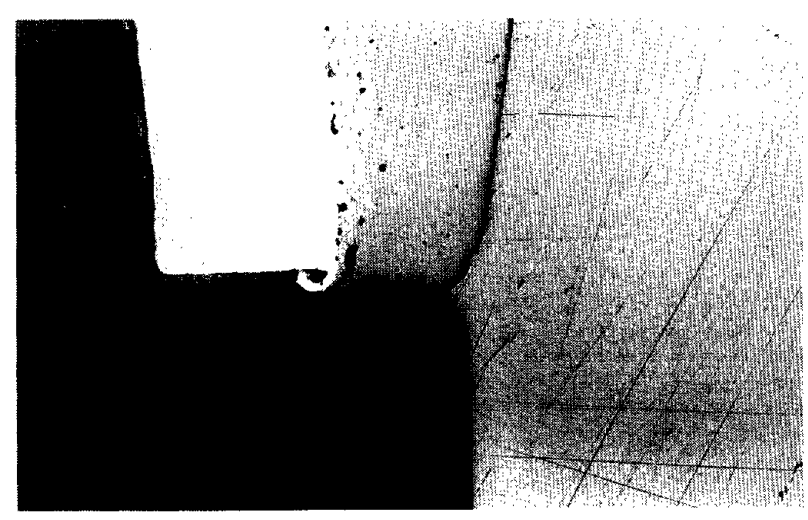

(c) $\mathrm{M}_{1-1}$

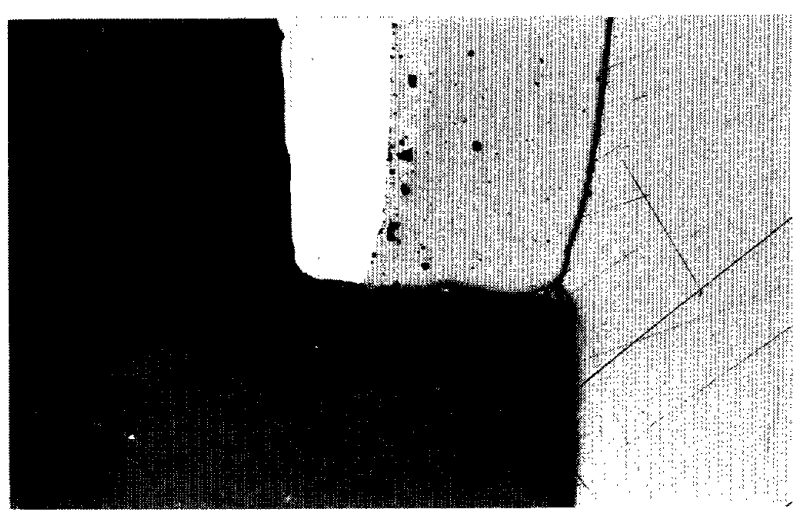

(b) $\mathrm{M}_{1-0}$

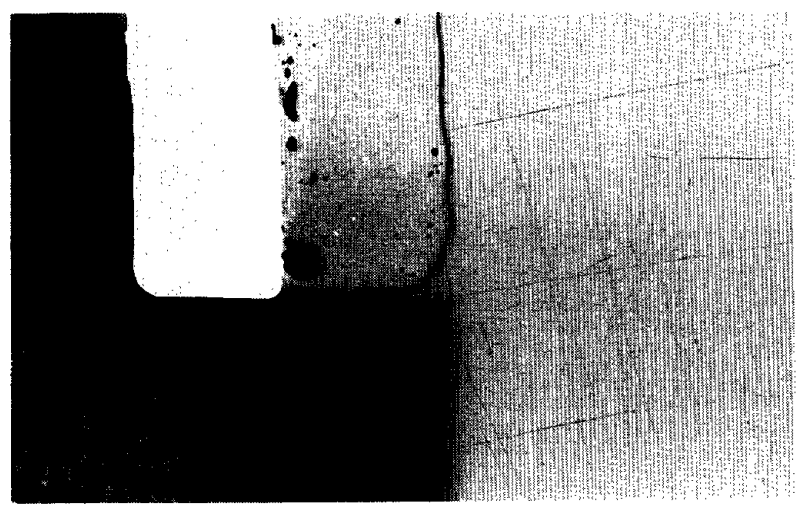

(d) $\mathrm{M}_{1-1.5}$

Fig. 18 Axial cross section around the corrected margin of ceramo-metal crown after cementation. 
は $50 \mu \mathrm{m}$ 程度にまでなった。

Fig. 18 は，マージン部を修正したクラウンをセメン 卜合着し，歯軸に沿った断面で観察したマージン部であ る、 $\mathrm{M}_{1-0}$ および $\mathrm{M}_{1-1}$ を用いて築盛した場合には良好な マージン部の適合状態を示しているが，蒸留水および $\mathrm{M}_{1-1.5}$ を用いた場合にはフィニッシングライン上に大き なギャップが認められた． $M_{1-2}$ を用いた場合す $M_{1-1.5}$ と 同様であった。

\section{考察}

I 、焼成収縮，気泡および圧縮強さ

光重合型モノマーを用いて築盛した場合，モノマーの 粘度が高いためポーセレン粉末を多量に混入することが 非常に困難である. とくに BDMA モノマー単独では, 振動法によるコンデンスの効果も少なく，混和できる粉 末量は蒸留水を用いた場合の $1 / 2$ 程度にすぎなかっ た.これは従来の築盛法から考えれば，著しくコンデン ス不足の状態にあるといえる. BDMA モノマ一を GMA モノマーで希釈することによって粘度が低下し， ポーセレン粉末の混入量は多くなった。希釈剤の量が多 くなるにつれて粉末量は多くなっていったが， $\mathrm{M}_{1-1.5}$ で はほぼ一定值に達し，それ以上希釈剤の量が増えても粉 末量には変化がみられなくなった。 その值は蒸留水を用 いた場合の $75 \%$ 程度でありここが BDMA モノマー を用いた場合の粉末混入量の限度であることがわかっ た.したがって，光重合法で築盛した場合には，蒸留水 を用いた場合の築盛物中にある粉末の $25 \%$ 以上がポリ マーに置き換えられており，築盛物のかなりの部分をポ リマーが占めていることになる，乾燥・焼成時にはこの ポリマーが燃焼して空隙をつくる，その空隙がポーセレ ンで埋められれば収縮が大きくなり，埋められなかった あのはポーセレン内に残留して気泡となる．本実験の結 果では，混和粉末量の少ないものほど収縮が大きくなる 傾向にあり，しか子焼成後のポーセレンの密度が $\mathrm{M}_{1-0}$ の場合を除いて蒸留水を用いて築盛したコントロール試 験片とほぼ同程度のあのとなった。このことは，モ， マーを用いた場合に余分に生じた空隙の大部分がポーセ レンで埋められたことを示している，そのためには，築 盛時に用いたモノマーがある程度連続したポリマーを生 成し，焼成時にガスが排出されやすい状態となっている ものと推測される， $\mathrm{M}_{1-0}$ の場合には，大きな焼成収縮を 示したにもかかわらず, 密度は小さいあのとなった。こ れは，築盛後にポリマーが占める割合があまりにも大き いため，ポリマーが焼却されたあとに生じた空隙が焼成
後もかなり残留していることを示すすの之考えられる。

また，減圧焼成を行った場合，焼成後の体収縮率およ び密度が大気焼成より大きくなる傾向が認められた，減 圧焼成による体収縮率は田外 $(1967)^{13)}$ ，浜 $(1966)^{147}$ により，それぞれ $45.5 \% ， 43.0 \%$ と報告されている．今 回の実験で得られた蒸留水を用いたコントロール試験片 の収縮率は，これらの值とほぼ同程度であった，光重合 法で築盛した場合には，モノマー中への混和粉末量の少 ないものほど大気焼成と減圧焼成との間の収縮量の差が 大きくなった。これは光重合後の築盛体の中でのポリ マーの占める割合が大きく，そのポリマーが焼却された あとに生じた大きな空隙を埋めるには，大気中での脱泡 作用では不十分なためである之思われる，700-900 ${ }^{\circ} \mathrm{C}$ の焼成温度でのポーセレン内部の観察結果 (Fig. 4) からわかるように, $750^{\circ} \mathrm{C}$ ですでにポーセレン粒子の溶 融は始まっており，この付近で咸圧していなければ空隙 は大きなまま残留してしまうことになる。このことは， $\mathrm{M}_{1-0}$ の場合に焼成後のポーセレン内の気泡の総面積率が 著しく大きいこと，ならびに $500 \mu \mathrm{m}^{2}$ 以上の大きな気泡 が他の場合より著しく多いことからも説明される。これ

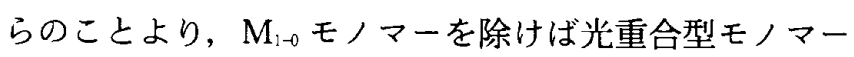
を用いた場合には，焼成収縮は大きいが，密度は蒸留水 を用いた場合とほとんど変わらないことがわかった。

また，希釈剤を含むモ/マーを用いた場合に，焼成後 のポーセレンの密度がコントロールと同程度であったに あかかわらず, 気泡の総面積率はコントロールよりかな り小さいものとなった，本実駼結果は，気泡の観察倍率 之画像解析処理装置の能力から測定可能な $48 \mu \mathrm{m}^{2}$ 以上 の大きさの気泡を対象としたものである. しかし，ポー セレン内部の顕微鏡観察によれば，微細な気泡が無数に

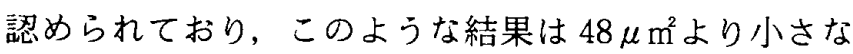
気泡が数多く残留しているためであると考えられる.

$\mathrm{M}_{1-0}$ を用いた場合，圧縮強さにも大きな影響があらわ れ，コントロールに比べて著しい強さの低下が認められ た. 強さには気泡の存在が最む大きく影響するあのと考 えられる。しかし、コントロールと希釈剤を含むモ， マー $\left(\mathrm{M}_{1-1}, \mathrm{M}_{1-1.5}, \mathrm{M}_{1-2}\right)$ を用いた場合との間には, 気 泡の面積率ならびに数にはかなりの差がありながら圧縮 強さに有意な差は認められず，微細な気泡は強さにあま り大きな影響をおよぼさないものといえる。臨界値は明 らかではないが， $\mathrm{M}_{1-0}$ の場合のようにある程度以上の大 きさの気泡が数多く存在すると強さの低下が生じること がわかった.

II. 表面性状 
一般に減圧焼成すると, 大気焼成した場合よりポーセ レン表面はあれやすいといわれている ${ }^{15}$ ：また，関 $(1984)^{16)}$ はグレージング後のステインを真空焼成を 行った場合，大気焼成で認められなかった大きな凹凸が 形成され，クレーター状の表面像を呈していたと報告し ている，本実験においてあ同様の表面像が認められ，蒸 留水を用いて築盛した場合，大気焼成に比較して減圧焼 成では表面あらさが約 5 倍に大きくなり，光沢度も $20 \%$ 程度低下した。これは減圧下で焼成することに よって, ポーセレン内部に残存する気泡が表面に向けて 移動し，一部は表面に抜けてクレーターとなり，一部は 表面下で泡粒を形成したためであると考えられる．この 泡粒が生じる主な原因としては，ポーセレン内部に多量 の気泡が存在すること，ならびにポーセレンが焼結して 表層が封鎖状態になったにすかかわらずそれ以上の真空 焼成を行うことなどが挙げられている17.

前述のように, 光重合法で築盛した場合には, ポーセ レン築盛物はコンデンスが不十分な状態になっており， ポーセレン内部に多くの気泡が存在することになる。 そ の結果, 減圧下での脱泡効果による凹凸発生の可能性が 高くなり，表面あらさが大きくなったものと思われる。 しかし, 電顕像にみられる表面の凹凸ならびにあらさ値 には，蒸留水を用いた場合と築盛時に使用した粉末量の 違いから予想されるほどの大きな差は認められなかっ た。モママーを用いた場合の減圧下での烧成収縮はかな り大きくなっており，ポリマーが燃焼したあとに生じた 空隙の多くは，おそらく溶融した表層部によって封鎖さ れる前の焼成の早い段階でポーセレンによって埋められ るのであろうと考えられる．希釈剤を加えて粘度を低下 させたモノマーを用いて築盛すると，滅圧焼成したあと の表面あらさは小さくなり，コントロール以下になる傾 向さえみられた，築盛時の使用粉末量は蒸留水を用いた 場合の $75 \%$ 以下であり,やはり十分にコンデンスされ た状態にあるとはいいがたい，しかし，焼成収縮は大き く，比較的大きな気泡が少なくなっていることから，あ る程度大きな空隙があるとかえって気泡が排出されやす い状態になるのかむしれないと推測される.

ポーセレンマージン部の表面あれは, 雨頸部にプラー クなどの付着を助長することになり，二次的な疾病を引 き起こす原因になる．これらのことから考えると，隇圧 烧成を行うより大気焼成を行った方が良好な結果が期待 される．しかし，内部に残留する気泡を少なくするため には，減圧焼成せざるを得ない，田外 $(1967)^{13)}$ は減圧 焼成を行う場合, 減圧度, 隇圧開始温度は表面あらさに
影響はおよぼさないが，減圧終了温度は有意に影響を与 えると報告していることから，モノマーを応用した場合 の焼成条件についてさらに検討を進める必要があると思 われる.

また，守川ら $(1982)^{18)}$, 鱒見ら $(1987)^{197}$ は，重合 した鋳造用レジンパターンを加熱すると大きな膨張を起 こすことを報告している。これは，鋳型を変形させた り，亀裂を生じさせる危険性があることを示唆してい る. 光重合型モノマーをポーセレンの築盛に応用した場 合も，同様な影響が危惧される。したがって，ポーセレ ンの築盛に応用するモノマーとしては，重合後加熱によ る膨張が少ないものを選ぶ必要がある。大石ら（1988 ）は，光重合型パターン用レジンモノマーをポーセレ ンの築盛に応用する試みを行っている，しかし，パ夕ー ン用レジンは加熱時の膨張が大きい上, 本研究の予備実 験で試用した結果では, 粘度が高く, 焼成時に多量のス スが発生し, ポーセレンの黒変が生じるなど, あまり好 ましい効果は得られなかった. BDMA モノマーを用い て築盛した場合, 蒸留水を使用した場合より焼成した ポーセレン表面のうねりがわずかながら大きくなる傾向 が認められた。うねりは大きな焼成収縮によっても起こ り得るが, 築盛後の乾燥・焼成時にポリマーが熱膨張を 起こしてポーセレンを変形させた結果生じた可能性す考 えられる。しかし，ポーセレンに亀裂が生じた例はまっ たく認められず，う权りも実用上大きな障害になるほど のものではないことから，これらの点に関しては BDMA モノマーは問題ないと考えられる.

III. 色調

色差の測定において，色調の違いを肉眼で識別できる 色差の閾値としては 1.0 から 4.0 まで種々の值が提唱さ れている ${ }^{20-24)}$. このような閾值の大きな相違は, 材料系 の違いによるところが大きいものと思われる. ポーセレ ンに対しては, 肉眼での判定と比較した結果, Stearns $(1951)^{25)}$ の報告した色差值 1.5 が䦨値として妥当であ ろうと判断された。ポーセレンの築盛に光重合型モノ マーを用いた場合, $\mathrm{M}_{1-2}$ で䦨值を越える色差があらわれ たが，他のモノマーでは色調におよぼす影響は認められ

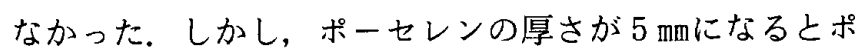
リマーの不完全燃焼によると思われる黒変が生じ, $4 \mathrm{~mm}$ 以下の試験片との間に大きな色差が認められるように なった，不完全燃焼はポーセレンが厚い場合だけではな く, 焼成温度が低い場合にも起こり得る. 本実験で温度 を変えて燒成を行った結果, $850^{\circ} \mathrm{C}$ 以下の温度ではポー セレン内部にあるポリマーの不完全燃焼によって黒変が 
生じやすいことがわかった，焼成温度が変われば，蒸留 水を用いて築盛した場合でも著しい色差がみられたが, モノマーを用いた場合には黒变も加わってさらに大きな 色差が認められた。しかし， $900^{\circ} \mathrm{C}$ で焼成すれば，黒変 あ消失し，蒸留水を用いた場合之色差も認められなく なった。臨床的にはポーセレンの厚さが $5 \mathrm{~mm}$ 越えるこ とはないので， $900^{\circ} \mathrm{C}$ で焼成するかぎり，BDM モ， マーを築盛に応用しても色調には影響をおよぼさないと 考えられる.

\section{IV. 歯型との分離性}

カラーレスセラモメタルクラウンのマージン部を修正 する際に，蒸留水を用いて修正用ポーセレンを築盛した 場合, 撤去後に超硬せっこう霜型上にかなり多量のポー セレン粉末の残留がみられた。歯型上でマージン部の隙 間にポーセレンを築盛すると，水分が急速に歯型に吸収 される.この水分の吸収はポーセレン粉末にコンデンス 効果をもたらすと思われるが，同時に歯型を濡らすこと によって粉末がポーセレンマージンより歯型表面の方に 付着しやすい状況を作り出しているあのと考えられる. 分離剤を塗布すると水分の吸収は多少抑制され，吸収速 度が低下するが，分離効果は十分であるとはいえない。 また，水分が歯型に吸収されて少なくなり，築盛物があ ろくなっていることも一部が㔀離して歯型上に残留する 要因のひとつと考えられる.

光重合型モノマー $\mathrm{M}_{1-0}$ を用いた場合には，モノマー の粘度が高くて歯型へ吸収されにくいこと，ならびに重 合したポリマーによって築盛したポーセレンが一体化 し，局所的な破折，㓦離が起こりにくくなることなどの ため，良好な歯型との分離性が得られたものと思われ る. $\mathrm{M}_{1-1}$ の場合あ分離性は良好であったが，希釈剤を含 む $\mathrm{M}_{1-1.5}$ および $\mathrm{M}_{1-2}$ を用いた場合には，せっこう㐘型の フィニッシングライン付近にかなり多量のポーセレン粉 末の残留が認められた。希釈剂が多くて重合率が低下 し，十分な強度が得られなかったのではないかというこ とがその原因のひとつとしてあげられる。また，モ， マーが希釈されて粘度が低下したため, 菌型に吸収され やすくなっている，雬型内に吸収されたモノマーむ光照 射することによって重合する．本実験ではマージン部の 軸面から照射したため, 歯型の深い部分で吸収されたモ ノマーには十分な光が到達せず，重合が不完全になりや すいが, フィニッシングライン付近の歯型内にあるモ， マーは十分な重合を起こし得る。その結果, 歯型内表層 のモノマーとポーセレン築盛物内のモノマーとが連続し たポリマーを形成し，比較的弱い築盛物の一部が剥離し
てフィニッシングライン上に集中して残留したものと推 測される。

歯型上にポーセレン粉末の残留が少ないほど，当然の ことながら焼成後のマージン部の適合性はよくなる。修 正前のポーセレンマージンと歯型ショルダーとのフィ ニッシングライン上での間隙量は $60 \mu \mathrm{m}$ 前後であった が，修正後には蒸留水を用いた場合で約 $40 \mu \mathrm{m}$ となっ たのに対して， $\mathrm{M}_{1-0}$ および $\mathrm{M}_{1-1}$ を用いて築盛すると 25 $\mu \mathrm{m}$ にまで隇少した。 セメント合着後の断面観察におい ても，これらのモノマーを用いた場合にはマージン部の 適合性が著しく改善された。

最近，従来のような水を用いない築盛法としてワック ス・ポーセレン・テクニックが行われるようになってき た.このテクニックに拈ける焼成時の体収縮率は James ら $(1986)^{26)}$ によると $23.4 \%$ 之報告されており， 本実験のモノマー使用の場合上り著しく小さい，しか し，ワックス・ポーセレン・テクニックではワックスの 粘度が高いためコンデンスがうまく行われず，築盛時に ポーセレン粉末を多量に混和することができないすのと 思われる，それにもかかわらず，焼成時の収縮が非常に 小さくなるとすれば, 密度の小さい, 多孔質のポーセレ ンとなることが予想され，十分な強度が得られない可能 性が考えられる.

本研究において試作した BDMAをべースモノマーと する光重合型モノマーの場合す粘度が高く，築盛時に混 入できるポーセレン粉末量は蒸留水を用いた場合の 50 75\%にすぎなかった，そのため，焼成収縮が大きく なった。 とくに希积剤を含まない $\mathrm{M}_{\mathrm{l}-0}$ を用いて築盛し た場合，著しくコンデンスが不十分な状態になり，良好 なマージン部の適合は得られたものの，焼成収縮が大き く，しかむ大きな気泡の残留も多く，密度，圧縮強さ， 表面性状などいずれにおいても著しく少る結果となっ た. BDMA をGMA で希釈したモノマーを用いると, これらの欠点は大幅に改善され，焼成収縮が大きいこと を除けば，気泡，密度，圧縮強さ，表面性状は蒸留水を 用いた場合と同等か，むしろそれより好ましくなる傾向 を示した，焼成収縮は小さいほど好ましいが， $\mathrm{M}_{1-0}$ およ び $\mathrm{M}_{1-1}$ をマージン修正用に用いると良好なマージン部 の適合性が得られており，本実験で単純な試験片につい てみられた程度の収縮の差は臨床上大きな問題とはなら ないものと思われる。モノマーがせっこう歯型に吸収さ れる際に多少コンデンス効果が起こる可能性も無視でき ないかもしれない，しかし，希釈剤が BDMAの 1.5 倍 以上加わると，コンデンス効果は増しても歯型との分離 
性が著しく悪くなり，マージン修正用には適さないもの となった。

以上のように，BDMA に GMA を 1：1 の割合で加 えて希釈した $\mathrm{M}_{1-1}$ モノマーは, 色調への影響もなく， 焼成後のポーセレンの性質を損なわずに操作性ならびに 適合性を著しく改善できることから，カラーレスセラモ メタルクラウンのマージン部修正用ポーセレンの光重合 による築盛法に用いられる有効な混和液として今後の臨 床応用が期待される.

\section{結論}

カラーレスセラモメタルクラウンは, マージン部の良 好な適合が得られにくい，そこで，本実験ではBDMA をベースモノマーとし，GMA を希积剤とした光重合型 モノマーを試作し，これを用いて築盛した場合の有用性 を検討した結果，以下の結論を得た。

1.モノマーの粘度が高いため, 築盛可能な範囲内で 混入できるポーセレンの最大粉末量は，希釉剤を含まな い $\mathrm{M}_{1-0}$ モノマーで蒸留水の場合の $50 \%$ 程度であった. 希釈剂を加えると粉末混入量は増加したが，最大值は 75\%であった。

2、焼成によるポーセレンの体収縮率は, 光重合法で 築盛することによって，10 から 15\% 増加した。その結 果, ポーセレンの密度は $\mathrm{M}_{1-0}$ で小さくなったことを除 いて，他ではいずれも同程度のものとなった。

3. $\mathrm{M}_{1-0}$ を用いた場合，焼成後のポーセレン内に 500 $\mu \mathrm{m}^{2}$ 以上の大きな気泡が著しく增加した．希积したモノ マーを用いると大きな気泡は減少し, 微細な気泡が増加 する傾向にあった。

4. 圧縮強さは $\mathrm{M}_{1-0}$ を用いた場合に著しく低下した が，希釈したモノマーを用いると, 蒸留水を用いた場合 と同程度かあるいはやや上回る傾向を示した.

5. 大気焼成したポーセレンは，蒸留水あるいはモ， マーのいずれを用いて築盛した場合も平滑な表面を呈し ていた. 減圧焼成すると, ポーセレン内部からの脱泡に よって表面に凹凸が生じ，表面あらさは大きくなり，光 沢度は低下した。この傾向はとくに $\mathrm{M}_{1-0}$ を用いた場合 に顕著であった。

6. 大気焼成した場合, いずれの混和液で築盛した ポーセレン間においても色差は肉眼で識別し得る閾値以 下の值であり，色調に変化は認められなかった．減圧焼 成すると， $\mathrm{M}_{1-2}$ を用いた場合のみが他との間で闌値を越

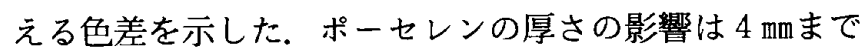
みられなかったが， $5 \mathrm{~mm}$ にると試験片に黒変があらわ
れ，著しく大きな色差が認められるようになった。

7. 焼成温度によって屯ポーセレンには著しい色差が あらわれた。 とくに，モノマーを用いた場合には $850^{\circ} \mathrm{C}$ より低い温度ではポリマーの不完全燃焼による著しい黒 変が認められた. $900^{\circ} \mathrm{C}$ 焼成で黒変は消失し, 蒸留水を 用いた場合と識別し得るほどの色差は認められなかっ た.

8.マージン部修正用ポーセレンを築盛した後せっこ う雬型から撤去する際に，蒸留水， $\mathrm{M}_{1-1.5}$ および $\mathrm{M}_{1-2}$ を 用いた場合には歯型との分離性が悪く，歯型ショルダー 上にかなり多量のポーセレン粉末の残留が認められた。

$\mathrm{M}_{1-0}$ および $\mathrm{M}_{1-1}$ を用いて築盛した場合には, 非常に優 れた歯型との分離性を示し，焼成後良好なマージン部の 適合が得られた。

9. 以上の結果から, 試作した光重合型モノマーの中 でBDMAを GMA で1：1に希瀵した $\mathrm{M}_{1-1}$ モノマーが 諸性質を損なわず操作性ならびにマージン適合性を改善 できる6のとして，マージン部修正用ポーセレンに非常 に有用であることがわかった。

稿を終わるにあたり，終始ご懇篤なるご指導とご校閲 を睗りました恩師内田康也教授ならびに九州歯科大学歯 科理工学講座小園凱夫教授に対し, 深甚なる感謝の意を 表するとともに, 本研究に対して数多くのご教示をいた だきました九州歯科大学歯科補綴学第 1 講座豊田静夫教 授に厚く御礼申し上げます。 また，終始実験にご協力を いただきました九州歯科大学歯科理工学講座柿川 宏助 教授, 田島清司講師に心から感謝致します。あわせて数 多くのご助言ならびにご協力いただきました補経学講座 および歯科理工学講座の皆様に厚く御礼申し上げます.

本論文の要旨の一部は, 平成 2 年 5 月 20 日, 九州歯 科学会総会, 平成 3 年 5 月 24 日, 第 85 回日本補綴学会 学術大会において発表した。

\section{引用文献}

1) 丸山剛郎, 尾島裕夫, 宮内修平, 下総高次：金属焼付ポー セレンの予後に関する臨床的研究, 第 4 報 歯肉の変化と 適合性との関連性. 補綴誌 17 (1):16-20, 1973.

2) 尾島裕夫：雪肉に対する金属焼付ポーセレン冠の影響に関 する実験的研究. 補経誌 22 (2) : 231-256, 1978.

3 ）丸山剛郎，下総高次：金属焼付ポーセレンの予後 一歯頸 部歯肉の変化に重点をおいた経過観察一. 歯界展望 40 (6) : $905-920,1972$.

4) 鬼塚 雅：陶材焼付貴金属冠の歯肉におよぼす影響に関す 
る実験的研究. 九州歯会誌 $35: 556-589,1981$.

5 ) 金子利雄：カラーレスポーセレン冠の歯肉組織におよぼす 影響. 九州歯会誌 41 (1) : 148-162, 1987.

6) Brecker, C. S. : Porcelain baked to gold-a new medium in prosthodontics. J. Prosthet. Dent. $11: 801$ $-810,1956$.

7 ) 末次恒夫, 南里孰仁, 大部彰義, 久保光弘, 永田良臣：力 ラーレス金属焼付ポーセレン冠, 第 2 報 適合状態の観 察. 補緅誌 $16: 485-492,1972$.

8 ）岩田健男，河津 寛：カラーレス・クラウンの臨床。歯界 展望 65 (3)：589-600， 1985.

9 ）内田康也，村上繁樹，上原秀樹，尾崎元則，小城辰郎，竹 内敏洋, 楪 雅行, 郭 明毅：カラーレスポーセレン冠の 基礎的研究. 九州霜会誌 38 (2) : 448-454, 1984.

10) Douglas, C. P., George, H. L. Jr. and James, G. E. : Light-cured porcelain margins: A new technique. J. Prosthet. Dent. 58 ( 1 ) : 50-52, 1987.

11) 大石 勝, 小野寺保男: 光重合型パターン用レジンパラ ビットBLCを応用したカラーレスセラモメタルクラウン の製作法. 歯科技工 16 (2) : 193-198， 1988.

12）御崎勝雄：加熱分離法によるポーセレンマージンの築盛と 焼成，一熱硬化型ハードニングリキッドを使用して，その 1 一。歯科技工 $19(10) ： 1125-1130 ， 1991$.

13）田外弘之：烧成陶材の咸圧焼成に関する研究 一国産低溶 陶材について一. 歯学 55 (3):327-346, 1967.

14）浜 元彰：国産低溶陶材の物理的性質と臨床的技法に関す 万研究. 霜学 54 (3) : 224-245, 1966.

15) Phillips, R. W. : Skinner's science of dental materials ( 9 th ed.). W. B. Saunders Co., Philadelphia, 505527,1991 .
16）関 正広：ポーセレンステインに関する基礎的研究. 九州 歯会誌 38 (6)：1109-1127, 1984.

17）保母須弥他訳：マクリーンの歯科陶材学. クインテッセン 又出版, 東京, $1980,45-49$.

18）守川雅雄, 豊田静夫, 三宅茂樹, 清水稔弘, 楊 欽栄, 井 上勝一郎：レジンパターン材料の性質，第 3 報 レジンと ワックスの寸法変化. 補経誌 26 (3)：599-604, 1982.

19）鱒見進一，守川雅雄，豊田静夫，柿川 宏，小園凱夫：レ ジンパターンの熱膨張による埋没材鋳型の亀裂発生. 九州 畨会誌 $41 （ 4) ： 834-838,1987$.

20）中川喜博：䨑冠色分析に関する研究。補経誌 19（1）: $109-130,1975$

21）宮内修平：歯科における色彩学. 日茵医師会誌 40 (5) : $552-561,1987$.

22）日本色彩学会編：新編色彩科学ハンドブック。大学出版 会, 東京, $1980,213-254$.

23）川上元郎：色の常識. 日本規格協会, 東京, 1982 .

24）村上智子，寺田善博，南原賢一，伊古野良一：陶材焼付金 属冠の色調に冠する基礎的研究，一ビ夕陶材の測色におけ る中川製作所製デンタルカラーアナライザーと日立製作所 製カラーアナライザーの比較一，補綴誌 35 (4)：689$699,1991$.

25) Stearns, E. I. : What's new in spectrophotometry : progress of spectrophotometry in the textile industry to 1951. Am. Dystuff. Report. 40:563-574, 1951.

26) James, A. S., Steven, E. D., Stephan, J. H. and Edward, T. H. : Volumetric shrinkage of a porcelain suspended in wax technique. J. Prosthet. Dent. 55 ( 3 ) : $302-304,1986$. 